\title{
DESENVOLVIMENTO DE UM PROTÓTIPO APLICADOR DE PRODUTOS QUÍMICOS PARA UM SISTEMA DE IRRIGAÇÃO PIVÔ CENTRAL
}

\section{ANDERSON SOARES PEREIRA}

Engenheiro Agrônomo

Orientador: Prof. Dr. JOSÉ ANTÔNIO FRIZZONE

Tese apresentada à Escola Superior de Agricultura "Luiz de Queiroz", Universidade de São Paulo, para obtenção do título de Doutor em Agronomia. Área de Concentração: Irrigação e Drenagem.

P I R A C I C A B A

Estado de São Paulo - Brasil

Fevereiro -2001 
Dados Internacionais de Catalogação na Publicação (CIP) DIVISÃO DE BIBLIOTECA E DOCUMENTAÇĀO - Campus "Luiz de Queiroz"/USP

\author{
Pereira, Anderson Soares \\ Desenvolvimento de um protótipo aplicador de produtos quimicos para um sistema de \\ irrigação pivô central / Anderson Soares Pereira. - - Piracicaba, 2001. \\ 64 p. : il. \\ Tese (doutorado) - Escola Superior de Agricultura Luiz de Queiroz, 2001. \\ Bibliografia. \\ 1. Agricultura irrigada 2. Desenvolvimento 3. Equipamento agricola 4. Irrigação por \\ pivô central 5. Produto químico I. Título
}

CDD 631.7

Permitida a copin to tal ou parcial deste documento desde que citadal a fonte - 0 autor? 
Aos Professores

José Antônio Frizzone

Durval Dourado-Neto e

Nilson Augusto Villa Nova

OFEREÇO

À minha esposa Maria Lucivânia Martins Noronha Soares 


\section{AGRADECIMENTOS}

A Deus, pela presença constante e pela força necessária para concluir esse trabalho.

Ao Prof. Dr. José Antônio Frizzone pela orientação, amizade e apoio irrestrito à minha formação.

Ao Prof. Dr. Durval Dourado-Neto pela orientação, amizade e apoio para a realização desta pesquisa.

Ao Prof. Nilson Augusto Villa Nova pela amizade, exemplo e incentivo a minha formação.

Ao Departamento de Engenharia Rural da ESALQ/USP, pela oportunidade de aperfeiçoamento e pelos ensinamentos recebidos.

Ao Departamento de Produção Vegetal da ESALQ/USP pelas facilidades e apoio para realização desta pesquisa.

Ao Conselho Nacional de Desenvolvimento Científico e Tecnológico (CNPq) pela bolsa de estudos concedida.

À empresa FABRIMAR Irrigação, na pessoa do Engenheiro Agrônomo Aymberê Boock, pelos equipamentos cedidos.

À empresa CARBORUNDUM Irrigação pelos materiais e pelas informações cedidas. 
À empresa PRO-INT comércio e representações, Piracicaba, SP, pelas facilidades para a aquisição de equipamentos.

Ao funcionário do Departamento de Produção Vegetal da ESALQ/USP, Sr. Antônio Arruda, pelo auxílio na montagem dos equipamentos.

Ao Engenheiro Agrônomo M.Sc. Edson Roberto Teramoto, do Departamento de Produção Vegetal da ESALQ/USP, pelo apoio aos trabalhos de campo.

Ao Engenheiro Agrícola M.Sc. Ênio Farias de França e Silva pelas sugestões referentes às análises químicas com as soluções de cloreto de potássio.

Ao Engenheiro Agrônomo Sílvio Carlos Ribeiro Vieira Lima pelo auxílio no ensaio da válvula reguladora de pressão.

À minha esposa Maria Lucivânia Martins Noronha Soares pelo auxílio nas montagens e ensaios de campo, e pelo carinho e incentivo durante a elaboração do trabalho.

A todos aqueles que direta ou indiretamente colaboraram para que este trabalho fosse realizado. 


\section{SUMÁRIO}

LISTA DE FIGURAS

Página vii

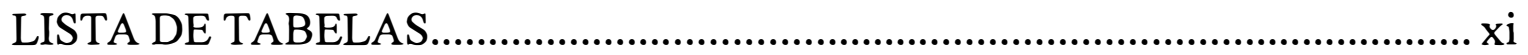

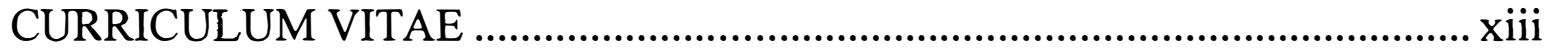

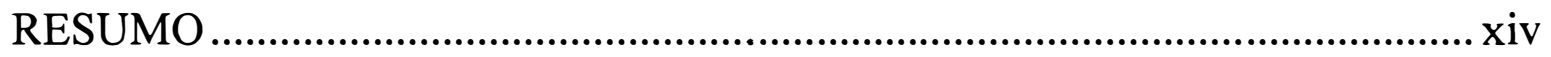

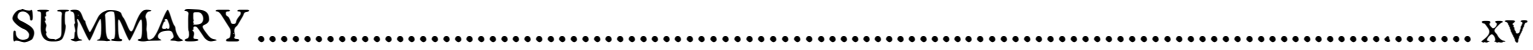

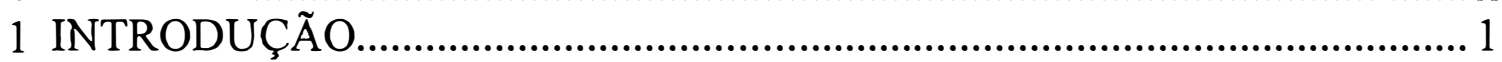

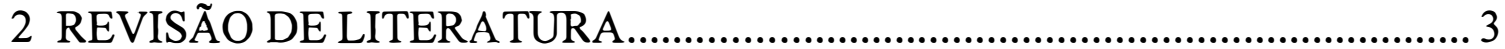

2.1 Sistema de irrigação pivô central................................................................... 3

2.2 Quimigação: conceitos, vantagens e desvantagens...................................... 5

2.3 Sistemas para aplicação de água e produtos químicos em sistemas de irrigação mecanizados ........................................................................... 7

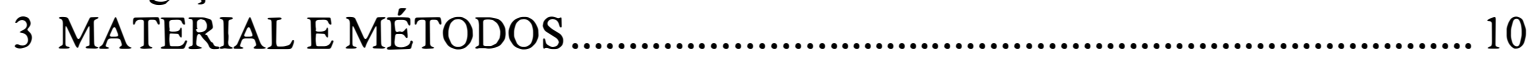

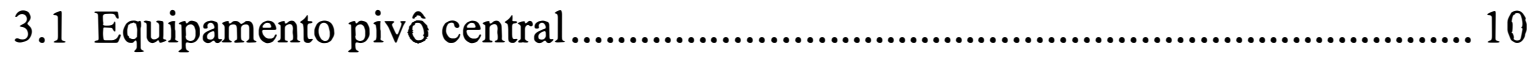

3.2 Descrição geral do protótipo....................................................................... 10

3.3 Desenvolvimento do protótipo .................................................................... 13

3.3.1 Desenvolvimento da unidade de bombeamento e filtragem ...................... 13

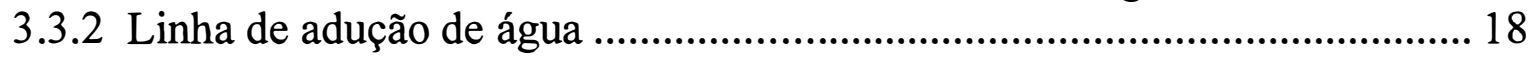

3.3.3 Desenvolvimento e componentes do cabeçal de controle.......................... 19

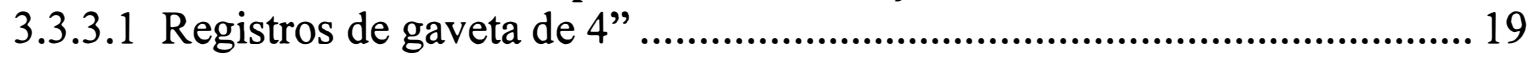

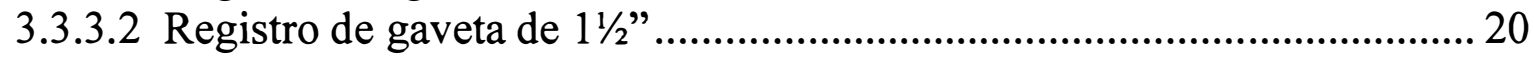

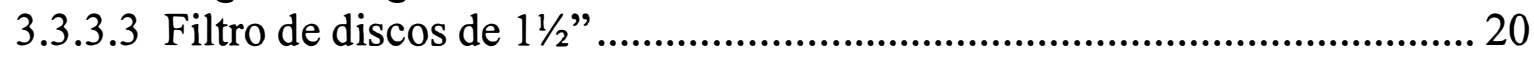

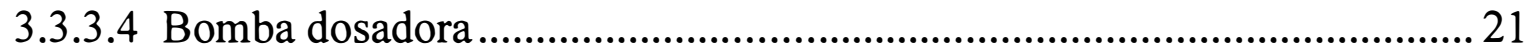

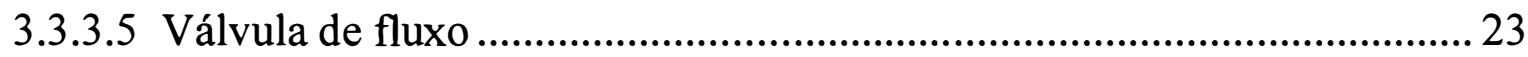

3.3.3.6 Chave geral de energia elétrica e chave de partida da bomba dosadora .. 23

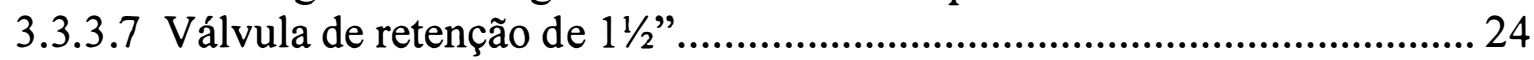

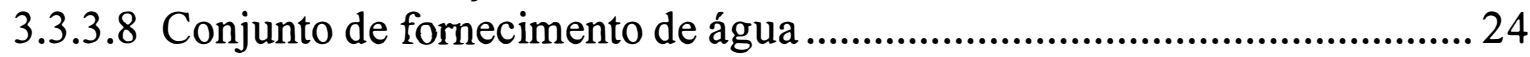

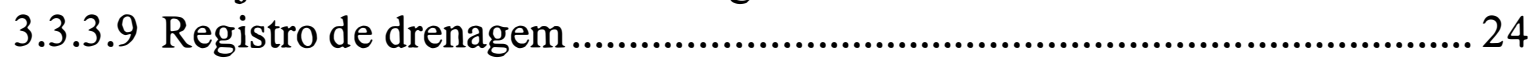

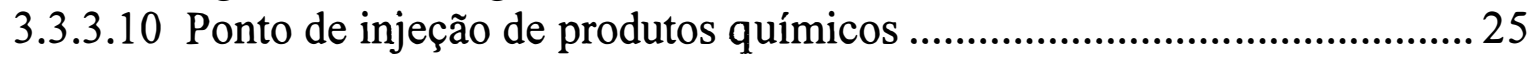

3.3.3.11 Conjunto de conexões e tubos de PVC................................................ 25

3.3.4 Desenvolvimento e componentes do sistema de adução de calda................ 25

3.3.4.1 Conjunto de acoplamento do cabeçal de controle a tubulação aérea ....... 25

3.3.4.2 Tubulações aéreas de adução de calda..................................................... 27

3.3.5 Desenvolvimento do conjunto de controle automatizado da emissão

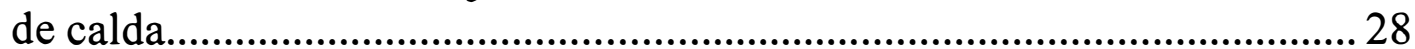

3.3.6 Desenvolvimento do conjunto de emissão de calda.................................. 29

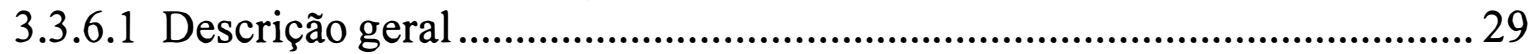

3.3.6.2 Características técnicas do microaspersor e componentes auxiliares ...... 31

3.3.6.3 Características técnicas da válvula reguladora de pressão ....................... 33

3.3.6.4 Metodologia para as estimativas das perdas de carga.............................. 35 
3.3.6.5 Diferenças de nível do terreno e cotas de localização dos

Página

microaspersores 35

3.3.6.6 Cálculo da vazão necessária aos microaspersores 35

3.3.7 Desenvolvimento do conjunto de acoplamento e regulagem da altura de aplicação.

3.4 Avaliações do protótipo a nível de campo................................................. 44

3.4.1 Avaliação da unidade de bombeamento e filtragem .................................. 44

3.4.2 Avaliação do cabeçal de controle ............................................................. 44

3.4.3 Avaliação do sistema de adução de calda ................................................. 44

3.4.4 Avaliação do conjunto de controle automatizado da emissão de calda........ 44

3.4.5 Avaliação do conjunto de emissão de calda ............................................. 45

3.4.6 Avaliação da uniformidade de distribuição de água ................................. 45

3.4.7 Avaliação da uniformidade de aplicação de produtos químicos pelo protótipo

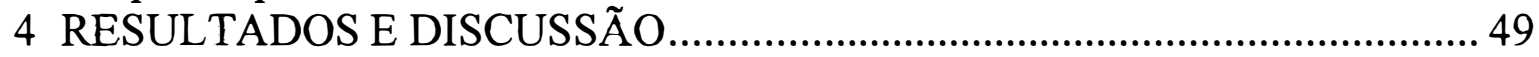

4.1 Avaliação da unidade de bombeamento e filtragem .................................... 49

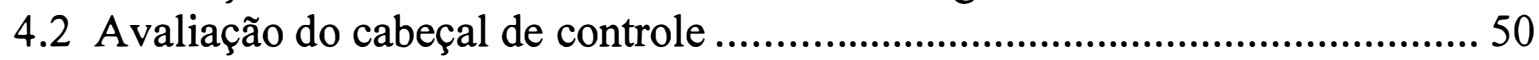

4.3 Avaliação do sistema de adução de calda.................................................... 50

4.4 Avaliação do conjunto de controle automatizado da emissão de calda ..........50 50

4.5 Avaliação do conjunto de emissão de calda ................................................. 50

4.6 Resultados do ensaio de uniformidade de distribuição de água...................... 57

4.7 Resultados do ensaio de uniformidade de aplicação de produtos químicos... 59

4.8 Desempenho do conjunto de acoplamento e regulagem da altura de

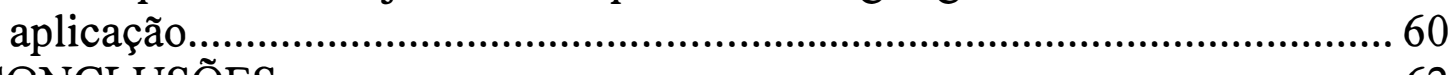

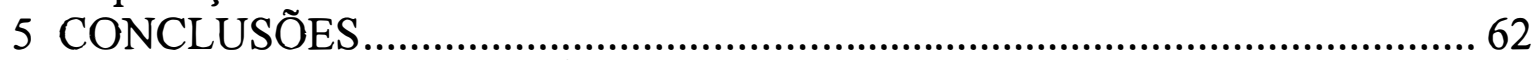

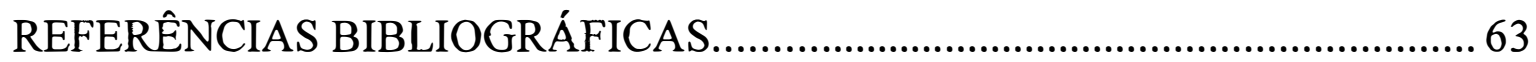




\section{LISTA DE FIGURAS}

Página

1 Esquema ilustrativo de alguns componentes de um sistema de irrigação do tipo pivô central (Marchetti, 1983): (a) ponto do pivô; (b) anel coletor; (c) emissor; (d) torre móvel; (e) lance em balanço; (f) ponto do pivô para sistemas móveis; (g) torre móvel; (h) junta articulada; (i) roda e pneu; e (j) canhão final.

2 Ilustrações do sistema com acoplamento de tubulações de PVC em um pivô central, apresentado por Tech Tips (1999): (A) tubulações de PVC, dotadas de pendurais, acopladas ao pivô central; (B) detalhe de uma braçadeira especial acoplando um tubo de PVC na tubulação metálica do pivô; $(\mathrm{C})$ detalhe das adaptações no vão inicial do pivô central para a derivação de água às tubulações de PVC.

3 Esquema ilustrativo dos componentes do protótipo aplicador de produtos químicos.

4 Componentes da unidade de bombeamento e filtragem: (1) Tubulação e conexões de sucção em PVC Linha Fixa DN-50 mm; (2) Conjunto Motobomba KSB Hydrobloc C-3000T; (3) Conexões de saída da motobomba, em PVC roscável DN 2": (4) Sistema de recirculação contínua de água; (5) Filtro plástico de discos 120 mesh, marca AMIAD, DN 1 1 1/2"; (6) Tubulação e conexões de recalque em PVC LF DN - $50 \mathrm{~mm}$.

5 Curvas características das motobombas KSB Hydrobloc, indicando a curva do modelo C 3000 (Fonte: Catálogo de produtos KSB Bombas Hidráulicas S.A)

6 Ilustração do sistema de recirculação contínua. (A) Componentes: (1) regulador de pressão FABRIMAR modelo EXACT-40; (2) conjunto de conexões em PVC de 3/4, com o bocal plástico adaptado; (3) registro de esfera $3 / 4$ " ; (4) Tubo de polietileno CARBORUNDUM, $20 \mathrm{~mm}$ de diâmetro interno. (B): Detalhe do bocal plástico cônico FABRIMAR, diâmetro $6,0 \mathrm{~mm}$, adaptado em nípel roscável de PVC de $1 / 2 "$ 
7 Conjunto de registros empregados na ligação da unidade de bombeamento na linha de adução de água: (1) motobomba para irrigação com pivô central; (2) registro de saída da motobomba do pivô central; (3) unidade de bombeamento do protótipo; (4) registro de saída da unidade de bombeamento do protótipo

8 Ilustração do cabeçal de controle: (1) registro de gaveta de 4"; (2) bomba dosadora de produtos químicos; (3) reservatório para produtos químicos; (4) chave geral de energia elétrica ; (5) chave de partida da bomba dosadora; (6) conjunto de fornecimento de água; (7) registro de gaveta de 11/2"; (8) filtro de discos MAC-LOREN; (9) válvula de retenção de 11/2"; (10) Registro de drenagem; (11) válvula de fluxo KSB hidroflow; (12) ponto de injeção de produtos químicos; (13) conjunto de conexões e tubos de PVC

9 Ilustração da bomba dosadora SODI-SCIENTIFICA modelo PD S: (1) disco graduado para regulagem de vazão; (2) Motor elétrico, $220 \mathrm{~V}$, trifásico, potência $0,12 \mathrm{cv}$; (3) conexões de sucção de produtos químicos; (4) ponto de amostragem de produtos químicos; (5) conexões de saída de produtos químicos a serem injetados.

10 Ilustração da válvula de fluxo KSB Hidroflow, com conexões de entrada e saída de 1"

11 Ilustração do conjunto de acoplamento do cabeçal de controle a tubulação aérea: (A) conexão no tubo de PVC $50 \mathrm{~mm}$ linha fixa; (B) conexão de saída do cabeçal de controle.

12 Tubulações aéreas do sistema de adução de calda: (A) primeiro vão do pivô; (B) lance em balanço

13 Braçadeiras do sistema de adução de calda: (a) braçadeira de aço chato galvanizado, (b) braçadeira de aço flexível galvanizado.....

14 Ilustração do conjunto de controle automatizado da emissão de calda: (1) válvulas solenóides ASCO; (2) válvula antivácuo MAC-LOREN; (3) conjunto de conexões em PVC; (4) registro de esfera de 1" para controle manual do fluxo de água. 
Página

15 Componentes do conjunto de emissão de calda: (1) tubo de polietileno, $26 \mathrm{~mm}$ de diâmetro interno; (2) válvula reguladora de pressão FABRIMAR, modelo EXACT-30; (3) tubo de polietileno, 20 mm de diâmetro; (4) microaspersores CARBORUNDUM, modelo multifunção.

16 Ilustração: (1) do microaspersor CARBORUNDUM modelo multifunção; (2) da válvula antigota L.P.D., marca DANSPRINKLERS, modelo "standard"; (3) dos conectores especiais "butterfly barb", marca DAN SPRINKLERS; (4) do tubo de polietileno com $20 \mathrm{~mm}$ de diâmetro interno.

17 Ilustração de dois microaspersores operando conjuntamente para a aplicação de calda em uma mesma área de domínio.

18 Visualização de um conjunto para acoplamento e regulagem da altura de aplicação instalado no pivô central: (1) braçadeira metálica; (2) tubo de PVC; (3) diagonal metálica em "V"; (4) cabo de aço; (5) cantoneira metálica perfurada; (6) linha de microaspersores.

19 Ilustração de uma braçadeira metálica de aço chato de 1" (A), dando suporte a uma cantoneira metálica (B).

20 Ilustração dos modelos de cantoneiras: (A) cantoneira lisa; (B) cantoneira perfurada.

21 Ilustração de um conjunto para acoplamento e regulagem da altura de aplicação, instalado no final do lance em balanço do pivô central..........

22 Localização dos conjuntos para acoplamento e regulagem da altura de aplicação ao longo do equipamento pivô central.

23 Ilustração do conjunto de estiramento da linha lateral: (1) cantoneira perfurada; (2) braçadeira plástica; (3) parafuso de fixação de 1/4"; (4) corrente auxiliar para fixação; (5) esticador para cabo de aço; (6) cabo de aço de $3 / 16$ "; linha de polietileno $20 \mathrm{~mm}$ de diâmetro 
Página

24 Ilustração do protótipo durante o período de parada da torre móvel (A) e durante o caminhamento da torre (B)

25 Conjunto de emissão de calda em funcionamento, instalado no primeiro vão do pivô central

26 Diagrama de dispersão entre a Vazão medida (L/h) e a Vazão estimada $(\mathrm{L} / \mathrm{h})$ dos microaspersores......................................................

27 Perfil das lâminas de água aplicadas pelos microaspersores; lâmina média de água aplicada; limites da faixa útil de aplicação e localização esquemática dos microaspersores.......................................

28 Variação das concentrações de potássio (ppm) aplicadas pelos microaspersores. 


\section{LISTA DE TABELAS}

Página

1 Especificações técnicas do equipamento de irrigação pivô central instalado na área experimental do Departamento de Produção Vegetal da ESALQ/USP, Piracicaba, SP.

2 Características técnicas gerais da bomba dosadora SODISCIENTÍFICA modelo PD S

3 Dados técnicos do microaspersor CARBORUNDUM multifunção: cor e diâmetro dos bocais; vazão dos bocais em diferentes pressões; diâmetro molhado pelo microaspersor operando invertido a $0,40 \mathrm{~m}$ de altura com a bailarina verde na pressão de $15 \mathrm{mca}$; máximo espaçamento entre emissores na linha; parâmetros da equação vazãopressão(Equação 1)

4 Pressões de saída (mca) medidas para diferentes vazões $(\mathrm{L} / \mathrm{h})$ com a válvula reguladora de pressão FABRIMAR, modelo EXACT-30, na pressão de entrada de $35 \mathrm{mca}$

5 Localização ao longo do pivô; distância entre conjuntos e distância ao ponto do pivô dos conjuntos para acoplamento e regulagem da altura de aplicação

6 Dimensionamento do conjunto de emissão de calda do primeiro vão: Número do trecho (TR.); distância ao ponto do pivô (DIST., m); comprimento do trecho (CP., $\mathrm{m}$ ); comprimento do trecho empregado no cálculo da perda de carga (CP hf., m); diâmetro dos bocais (D.B, $\mathrm{mm}$ ); número de emissores no final do trecho (N.E, m); vazão necessária, (VAZÃO NEC., L/h); vazão estimada a ser aplicada pelo microaspersor (VAZÃO APL., L/h); variação percentual entre a vazão estimada a ser aplicada pelo microaspersor e a vazão necessária (VAR. VAZÃO, \%); diferença de nível no trecho (aclive), (D.N, m); vazão do trecho (VAZÃO ACUM., L/h); diâmetro interno da tubulação de polietileno no trecho $(\mathrm{D}, \mathrm{mm})$; perda de carga no trecho (Hf, mca); pressão de operação do microaspersor (PF, mca) 
7 Dimensionamento do conjunto de emissão de calda do lance em balanço: Número do trecho (TR.); distância ao ponto do pivô (DIST., $\mathrm{m})$; comprimento do trecho (CP., $\mathrm{m})$; comprimento do trecho empregado no cálculo da perda de carga (CP hf., m); diâmetro dos bocais (D.B, mm); número de emissores no final do trecho (N.E, m); vazão necessária, (VAZÃO NEC., L/h); vazão estimada a ser aplicada pelo microaspersor (VAZÃO APL., L/h); variação percentual entre a vazão estimada a ser aplicada pelo microaspersor e a vazão necessária (VAR. VAZÃO, \%); diferença de nível no trecho (aclive), (D.N, m); vazão do trecho (VAZÃO ACUM., L/h); diâmetro interno da tubulação de polietileno no trecho (D, $\mathrm{mm})$; perda de carga no trecho (Hf, mca); pressão de operação do microaspersor (PF, mca)......

8 Local de medida da pressão; pressão medida (mca) e pressão estimada (mca) referentes ao conjunto de emissão de calda do primeiro vão.......

9 Local de medida da pressão; pressão medida (mca) e pressão estimada (mca) referentes ao conjunto de emissão de calda do lance em balanço

10 Distância do microaspersor em relação ao ponto do pivô (DIST.); Vazão estimada (L/h); Vazão medida (L/h) e Variação percentual (\%) entre a Vazão medida (L/h) em relação a Vazão estimada $(\mathrm{L} / \mathrm{h})$.............

11 Número do coletor; distância ao ponto do pivô (m) e lâmina média de água coletada $(\mathrm{mm})$, referentes ao ensaio de distribuição de água..........

12 Valores das concentrações de potássio (ppm) aplicadas pelos microaspersores 


\section{CURRICULUM VITAE}

Anderson Soares Pereira nasceu em 21 de setembro de 1971, no município de Santo André, Estado de São Paulo.

Em 1989 conclui o curso de Técnico em Agropecuária na ETAESG "Benedito Storani", em Jundiaí, SP.

Graduou-se Engenheiro Agrônomo pela Escola Superior de Agricultura "Luiz de Queiroz" - ESALQ, Universidade de São Paulo, em 1994.

Durante o curso de graduação em Engenharia Agronômica foi estagiário do Departamento de Engenharia Rural da ESALQ/USP, sendo bolsista de Iniciação Científica do Conselho Nacional de Desenvolvimento Científico e Tecnológico (CNPq) e da Fundação de Amparo à Pesquisa no Estado de São Paulo (FAPESP).

Em 1997 concluiu o curso de Pós-Graduação em Irrigação e Drenagem, à nível de Mestrado, pela ESALQ/USP.

Em 1997 iniciou o curso de Doutorado em Agronomia, Área de Concentração Irrigação e Drenagem, na ESALQ/USP.

Atualmente atua como assessor técnico em projetos e avaliações de sistemas de irrigação. 


\title{
DESENVOLVIMENTO DE UM PROTÓTIPO APLICADOR DE PRODUTOS QUÍMICOS PARA UM SISTEMA DE IRRIGAÇÃO PIVÔ CENTRAL
}

\author{
Autor: ANDERSON SOARES PEREIRA \\ Orientador: Prof. JOSÉ ANTÔNIO FRIZZONE
}

\section{RESUMO}

Empregando-se um sistema de irrigação pivô central composto por um vão inicial, uma torre móvel e um lance em balanço, foi desenvolvido um protótipo para aplicação de produtos químicos, operando de forma acoplada ao equipamento, utilizando-se da mobilidade da torre como meio de deslocamento para a aplicação de calda através de emissores do tipo microaspersor. Para tanto, foram desenvolvidos diversos conjuntos de componentes, que consistem em: unidade de bombeamento; sistema de filtragem de água e injeção de produtos químicos através de uma bomba dosadora; sistema de adução de calda acoplado a tubulação aérea do pivô central; sistema de controle automatizado da emissão de calda e um conjunto de suporte da linha de microaspersores. Desenvolveu-se uma metodologia para o dimensionamento hidráulico do sistema. Uma solução de cloreto de potássio $(\mathrm{KCl})$, em alta concentração, foi aplicada por uma bomba dosadora. Através de ensaios de campo concluiu-se que o protótipo apresentou uma boa uniformidade de aplicação de água e de potássio e que os procedimentos de cálculo adotados apresentaram alta exatidão, com as vazões e pressões medidas com valores próximos aos calculados. 


\title{
DEVELOPMENT OF A PROTOTYPE TO APPLY CHEMICALS FOR THE CENTER PIVOT IRRIGATION SYSTEM
}

\author{
Author: ANDERSON SOARES PEREIRA \\ Adviser: Prof. JOSÉ ANTÔNIO FRIZZONE
}

\section{SUMMARY}

Using a center pivot with a single mobile tower, a prototype to apply chemicals was developed, operating attached to the irrigation system equipment, using the mobility of the tower to apply chemical solution with minisprinklers. Different components were developed: a pump unit, a water filtering and chemical injection systems using a metering pump; an adduction system attached to the aerial tube of the center pivot; an automatic control system to apply chemical solution; and a mini-sprinklers support equipments. A methodology was developed for hydraulic system design. A high concentration potassium chloride solution was applied using the metering pump. The field experiment results allowed to conclude that the prototype presented a good water and potassium application uniformity, and the adopted calculation procedure presented high accuracy, because the estimated and measured values of the flow and pressure were similar. 


\section{INTRODUÇÃO}

O sistema de irrigação mecanizado do tipo pivô central tem contribuído substancialmente para a expansão da área irrigada no Brasil e no mundo. As facilidades para a sua implantação e operação, juntamente com a sua grande eficiência quando adequadamente projetado permite que a alternativa do cultivo irrigado com esse equipamento seja cada vez mais difundida e popularizada entre os empresários rurais. Já existiam em 1995 cerca de 5000 equipamentos pivô central instalados em território nacional, principalmente nos estados de São Paulo, Minas Gerais, Goiás, Bahia e Espírito Santo (Coelho, 1996). De acordo com os principais fabricantes e distribuidores desse equipamento no país, no início do século 21 a demanda nacional prevista será de aproximadamente 1000 novos equipamentos ao ano, mostrando a grande aceitação e difusão do sistema.

O pivô central permite a aplicação de produtos químicos via água de irrigação, possibilitando grande economia na aplicação de fertilizantes, principalmente com os adubos nitrogenados e potássicos. A aplicação de defensivos agrícolas via água de irrigação é objeto de muitas pesquisas na ciência agronômica, visando-se sua viabilidade técnica, econômica e ecológica. De acordo com Dourado-Neto \& Fancelli (1999), em sistemas do tipo pivô central, as aplicações via água de irrigação de fungicidas, inseticidas e herbicidas pósemergentes, que têm como alvo a parte aérea da planta, tendem a apresentar uma eficiência relativamente baixa devido ao alto volume de calda aplicado. 
No presente trabalho teve-se como objetivo desenvolver um protótipo aplicador de produtos químicos para um sistema de irrigação pivô central, utilizando-se da mobilidade da torre como meio de deslocamento para a aplicação de baixos volumes de calda através de emissores do tipo microaspersor. 


\section{REVISÃO DE LITERATURA}

\subsection{Sistema de irrigação pivô central}

De acordo com Marchetti (1983) o pivô central consiste basicamente em diversos emissores fixados sobre uma tubulação de comprimento variável, suportada longitudinalmente por uma série de torres, que se movimentam sobre rodas ao redor de um ponto central denominado ponto do pivô. Para suportar o vão livre do pivô entre torres adjacentes, existe uma estrutura de treliças e tirantes que mantém a tubulação a uma determinada altura do solo (4 a 5 metros) compatível com as culturas a serem irrigadas. A Figura 1 apresenta um esquema ilustrativo de alguns componentes de um pivô central.

O deslocamento de toda a linha lateral do pivô central no campo é comandado pelo andamento da torre mais externa. Supondo, inicialmente, que todas as torres estejam alinhadas e apenas a última se movimente, o acionamento do motorredutor da torre subseqüente se processa quando o vão em movimento se deflete em relação aos demais. Continuando o processo entre todos os vãos adjacentes, promove-se a movimentação de toda a linha de irrigação, pelo funcionamento intermitente dos motorredutores das torres. Embora a velocidade angular de deslocamento do pivô central seja constante, a velocidade média de caminhamento de cada torre deve ser progressivamente maior a partir do ponto do pivô, de maneira a induzir o movimento circular do equipamento na área. Como a área irrigada por cada torre também é progressivamente maior, aumenta-se 
também a vazão dos emissores ao longo da linha lateral do equipamento, objetivando que toda a área irrigada receba a mesma lâmina de água de maneira uniforme. Dessa forma, têm-se elevadas intensidades de aplicação de água na extremidade final do pivô e pequenas intensidades de aplicação próximo ao ponto do pivô.

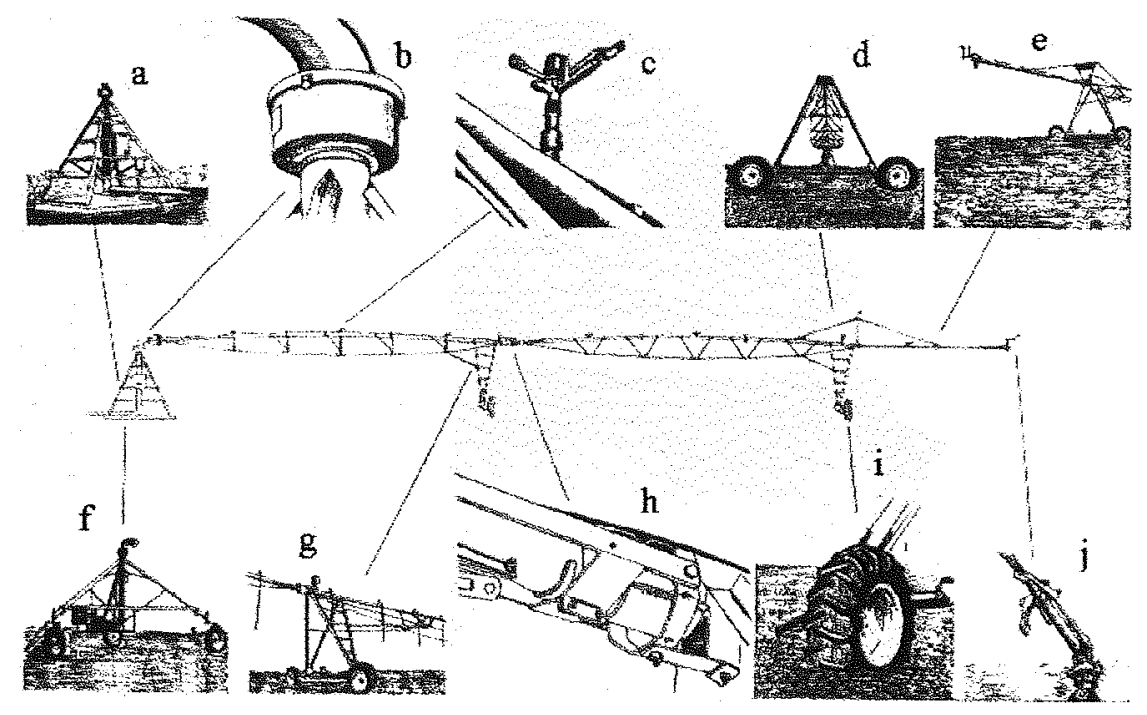

Figura 1 - Esquema ilustrativo de alguns componentes de um sistema de irrigação do tipo pivô central (Marchetti, 1983): (a) ponto do pivô; (b) anel coletor; (c) emissor de água; (d) torre móvel; (e) lance em balanço; (f) ponto do pivô para sistemas móveis; (g) torre móvel; (h) junta articulada; (i) roda e pneu; (j) canhão final.

O tamanho do equipamento pode variar de 20 a 150 ha, sendo o tamanho médio dos equipamentos comercializados no Brasil de 70 ha e nos EUA de 50 ha (Coelho, 1996). As áreas irrigadas entre as torres iniciais são menores do que as áreas irrigadas entre as torres finais do equipamento, sendo que o custo de cada vão é praticamente o mesmo, independente da posição ao longo do equipamento. Portanto, quanto maior o equipamento menor o custo por unidade de área. 


\subsection{Quimigação: conceitos, vantagens e desvantagens}

Segundo Dourado-Neto \& Fancelli (1999) entende-se por quimigação a técnica de aplicação de produtos químicos via água de irrigação. De acordo com o produto utilizado na quimigação pode-se ter a herbigação, quando são aplicados herbicidas; fungigação quando são aplicados fungicidas e insetigação quando aplicam-se inseticidas via água de irrigação. Há ainda a possibilidade de utilização de outros produtos químicos como nematicidas na nematigação e a aplicação de hormônios de crescimento, técnicas essas de utilização inexpressiva em nosso meio. Na aplicação de fertilizantes via água de irrigação, temos a fertirrigação, que tem por objetivo a aplicação de fertilizantes e água de irrigação e a fertigação que tem por objetivo apenas a aplicação de fertilizantes.

O protótipo desenvolvido neste trabalho não utiliza a água de irrigação para a aplicação de produtos químicos e, portanto, não pode ser classificado como um equipamento de quimigação, porém, como emprega a estrutura do sistema pivô central e a sua mobilidade sobre o terreno, algumas vantagens da quimigação, descritas por Schimidt (1997), podem ser atribuídas ao protótipo: (i) aplicação uniforme: reduzida possibilidade de sobreposição de faixas e de não aplicação em determinadas áreas do terreno, comum em sistemas tratorizados; (ii) ativação e incorporação: com a aplicação de maiores volumes de calda, quando comparado aos sistemas tradicionais de aplicação via tratorizada e aérea, pode-se promover a incorporação necessária para alguns tipos de defensivos como herbicidas pré-emergentes; (iii) redução na compactação do solo: devido a redução no tráfego de máquinas para aplicação de defensivos, podemos ter reduções significativas no grau de compactação dos solos ao longo do ciclo das culturas irrigadas, com conseqüente aumento do rendimento das culturas e melhor aproveitamento da água aplicada pela irrigação; 
(iv) redução de danos mecânicos às culturas: com a entrada de máquinas na lavoura, ocorrem perdas de produção pelo amassamento da cultura, abortamento de flores, entre outros. Essas perdas, segundo Schimidt (1997), através de informações recebidas de instituições de pesquisa como a EMBRAPA, IAPAR e IAC podem chegar a $3 \%$ para a soja; 3 a $5 \%$ para o milho; 5 a $8 \%$ para o feijão (podendo chegar até $12 \%$ no período de florescimento); 5 a $8 \%$ para o trigo e 10 a 15\% para a batata e o tomate; (v) aplicação de acordo com as recomendações: pela possibilidade de aplicar os defensivos em condições climáticas onde a aplicação via aérea ou tratorizada é inviabilizada, como em condições de velocidades de vento moderadas, o sistema para aplicação de defensivos agrícolas via pivô central possibilita que as aplicações sejam feitas no momento exato do estádio de desenvolvimento da cultura ou no momento de maior susceptibilidade das culturas a pragas e doenças; (vi) menor disseminação de pragas e doenças: conforme Dourado-Neto \& Fancelli (1999) com a fungigação (e alternativamente, com a aplicação de fungicidas pelo protótipo) pode-se minimizar a disseminação de fungos e patógenos, como também minimizar a disseminação de insetos com o emprego de inseticidas; (vii) menores riscos de contaminação ambiental: seguindo-se as recomendações dos fabricantes de defensivos agrícolas e com a utilização de equipamentos de segurança necessários; (viii) menores riscos de contaminação dos operadores: uma grande vantagem do protótipo desenvolvido, devido ao reduzido número de recargas de defensivos agrícolas e menor número de operadores quando comparados aos outros métodos de aplicação.

$\mathrm{Na}$ aplicação de fertilizantes, o protótipo desenvolvido apresenta as seguintes vantagens potenciais: (i) evitar problemas de corrosão no pivô central, devido a calda não ser conduzida nas tubulações metálicas do equipamento; (ii) viabilizar o emprego de alguns adubos foliares, com aplicação de baixos volumes de calda, possibilitando melhor retenção foliar dos nutrientes aplicados. 
Algumas limitações da quimigação e, também, do protótipo aplicador, é que nem todos os produtos químicos empregados em outras técnicas de aplicação poderão ser utilizados, evidenciando a necessidade do desenvolvimento de pesquisas nessa área.

\subsection{Sistemas para aplicação de água e produtos químicos em sistemas de irrigação mecanizados}

Lyle e Bordovsky (1986) desenvolveram um sistema para aplicação de produtos químicos em um sistema de irrigação mecanizado do tipo linear móvel, empregando bocais especiais com baixa vazão e grande alcance de cobertura, instalados em uma rede hidráulica independente, acoplada na estrutura metálica do linear móvel. Os bocais foram instalados de forma a cada um deles aplicar os produtos químicos sobre uma linha de cultura, com volumes de aplicação na ordem de 3140 litros por hectare. Experimentos de campo com as culturas de milho, algodão, sorgo e soja mostraram que os tratamentos onde foi empregado o sistema desenvolvido apresentaram melhores resultados, quando comparados aos tratamentos que empregaram a aplicação de produtos químicos via água de irrigação, com volumes de calda na ordem de 21500 litros por hectare. Uma limitação desse sistema é que requer o alinhamento dos bocais de pulverização nas linhas das culturas e, assim, o sistema de irrigação deve ser um linear móvel. No caso da instalação em um sistema pivô central, as culturas devem ser cultivadas em linhas de formato circular.

Sumner et al. (1997) apresentam um sistema para aplicação de produtos químicos, instalado em dois sistemas de irrigação pivô central: um pivô com quatro torres móveis e um pivô com uma torre móvel. Como emissores foram utilizados microaspersores espaçados de 3 a 3,6m, instalados em uma linha 
de polietileno. Os valores dos coeficientes de uniformidade de distribuição de água, obtidos em ensaios de campo e através de modelos de simulação, variaram entre 87 a $95 \%$.

Sumner et al. (2000) realizaram um trabalho onde foi avaliada a eficiência da aplicação de herbicidas pré e pós-emergentes no controle de plantas daninhas; fungicidas na cultura do feijão e desfolhantes na cultura do algodão. Os defensivos foram aplicados via quimigação; sistemas de pulverização tratorizados e pelo sistema utilizando microaspersores acoplados ao sistema de irrigação pivô central, apresentado por Sumner (1997). Concluíram que os herbicidas préemergentes e os desfolhantes aplicados via quimigação e pelo sistema de microaspersores acoplados ao pivô apresentaram resultados similares. $\mathrm{Na}$ aplicação de fungicidas, o sistema tratorizado apresentou melhores resultados devido a melhor retenção foliar da calda aplicada.

Dourado-Neto \& Fancelli (1999) apresentam o sistema NOTLIADA para aplicação de produtos químicos em sistemas de irrigação pivô central, que tem por finalidade adequar o volume de calda para aplicar de forma apropriada a quantidade de princípio ativo no alvo folha. O sistema propõe um procedimento de automação em que a aplicação de calda é interrompida, através de válvulas solenóides, quando ocorre a parada da torre do pivô central, tendo-se a aplicação de calda apenas quando o motorredutor da respectiva torre estiver em pleno funcionamento.

Omary et al. (1997) desenvolveram um sistema para operar de forma acoplada a estrutura metálica do pivô central, que possibilita a aplicação de diferentes lâminas de água sem variar a velocidade de deslocamento do pivô, através de um sistema de linhas paralelas dotadas de emissores com diferentes vazões, controladas por válvulas solenóides. Quando se deseja aplicar uma determinada lâmina de água, coloca-se em funcionamento uma ou mais linhas através da abertura de suas respectivas válvulas solenóides. 
Em Tech Tips (1999) é apresentado uma sistema onde tubulações de PVC são acopladas na tubulação metálica do pivô central através de braçadeiras especiais. A água de irrigação é conduzida através dos tubos de PVC, onde também são instalados os pendurais e os emissores para a aplicação da água de irrigação, ficando o pivô central apenas dando suporte a esses tubos, conforme apresentado na Figura 2. Esse sistema é adotado em algumas regiões dos Estados Unidos, principalmente em San Angelo, estado do Texas, devido ao alto poder corrosivo das águas, que torna inutilizáveis as tubulações de aço do pivô central em menos de dez anos. Segundo Tech Tips (1999) esse sistema apresenta menores custos de investimento, quando comparado aos custos de troca das tubulações de aço danificadas no pivô central, como também maior vida útil, devido ao PVC ser resistente ao poder corrosivo das águas.

(A)

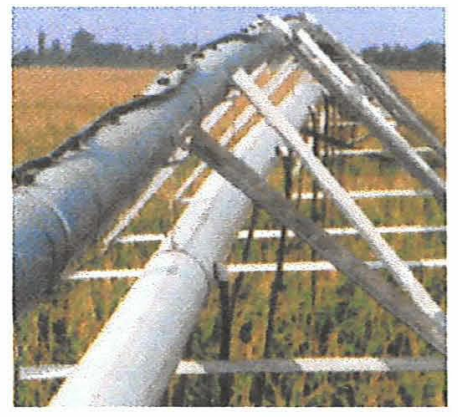

(B)

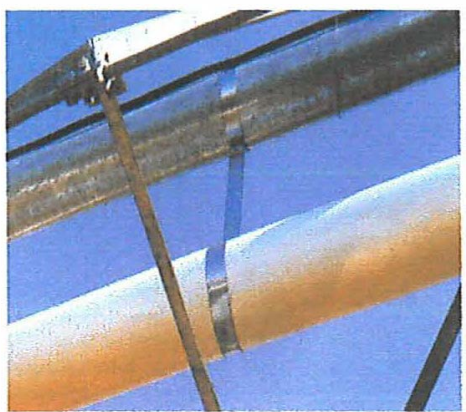

(C)

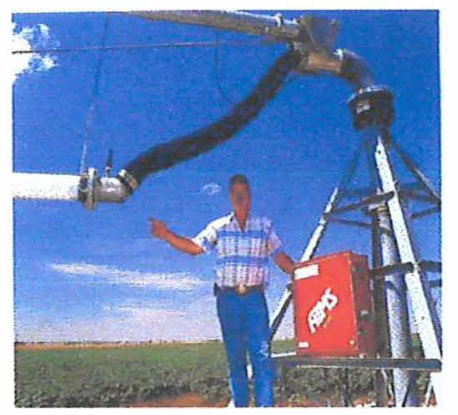

Figura 2 - Ilustrações do sistema com acoplamento de tubulações de PVC em um pivô central, apresentado por Tech Tips (1999): (A) tubulações de PVC, dotadas de pendurais, acopladas ao pivô central; (B) detalhe de uma braçadeira especial acoplando um tubo de PVC na tubulação metálica do pivô; $(C)$ detalhe das adaptações no vão inicial do pivô central para a derivação de água às tubulações de PVC. 


\section{MATERIAL E MÉTODOS}

\subsection{Equipamento pivô central}

O trabalho foi desenvolvido em um equipamento de irrigação do tipo pivô central instalado na área experimental do Departamento de Produção Vegetal da Escola Superior de Agricultura "Luiz de Queiroz", Universidade de São Paulo, Piracicaba, SP. As especificações técnicas do equipamento pivô central estão descritas na Tabela 1.

\subsection{Descrição geral do protótipo}

O protótipo desenvolvido é constituído pelos seguintes conjuntos de componentes, apresentados esquematicamente na Figura 3: (i) unidade de bombeamento e filtragem: localizado junto ao reservatório de água; o qual tem a finalidade de fornecer água pressurizada para o sistema, como também realizar a filtragem de água; (ii) linha de adução de água: adutora em PVC que conduz a água pressurizada até o ponto do pivô-central; (iii) cabeçal de controle: localizado no ponto do pivô central, recebe água pressurizada, realiza nova filtragem e adiciona a solução de produtos químicos (defensivos agrícolas ou fertilizantes) através de uma bomba dosadora, formando a calda; (iv) conjunto de 


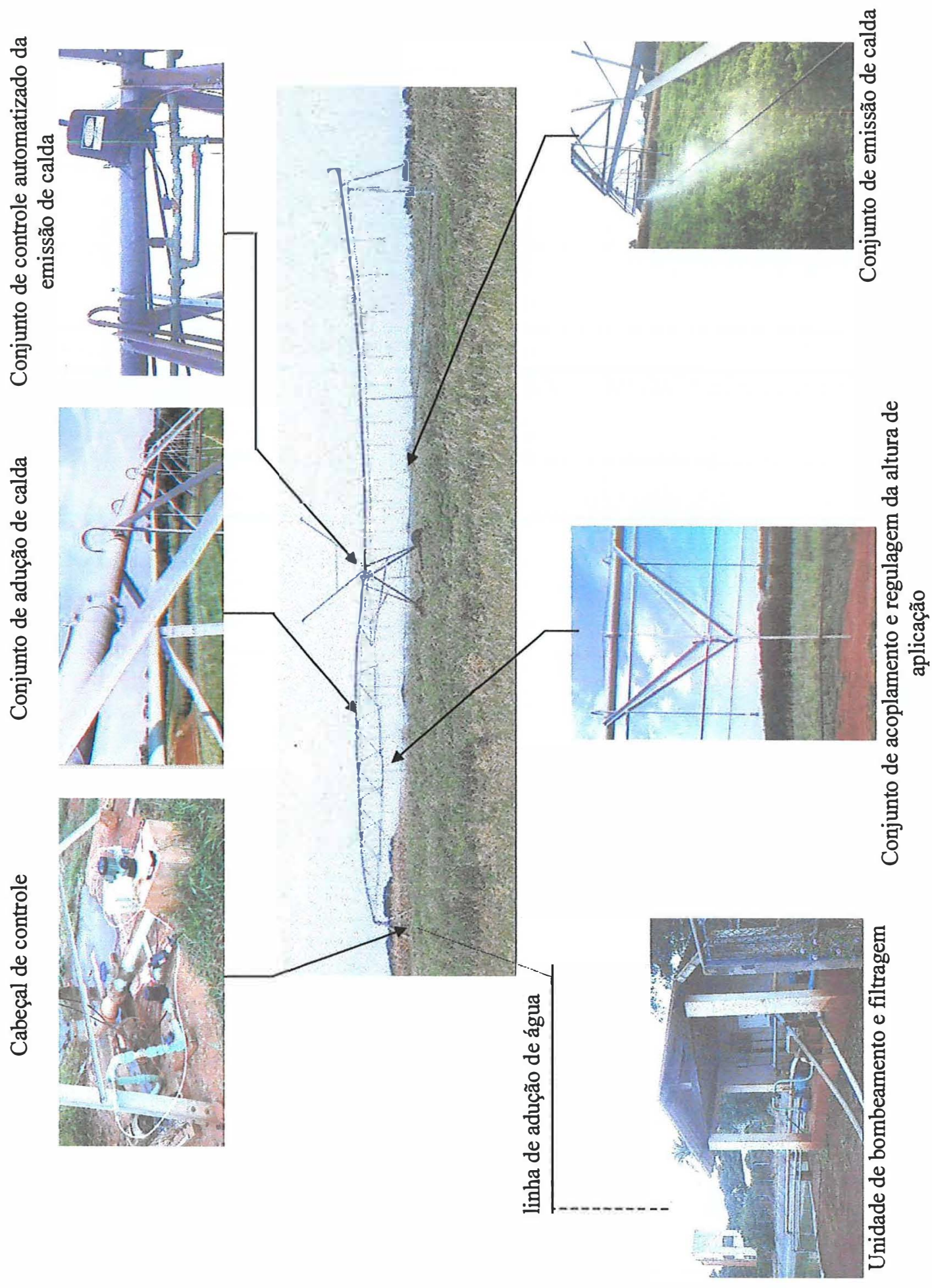

Figura 3 - Esquema ilustrativo dos componentes do protótipo aplicador de produtos químicos. 
Tabela 1 - Especificações técnicas do equipamento de irrigação pivô central instalado na área experimental do Departamento de Produção Vegetal da ESALQ/USP, Piracicaba, SP.

\begin{tabular}{|c|c|}
\hline MARCA E MODELO: & $\begin{array}{l}\text { Pivô central CARBORUNDUM, modelo MPC 630/01-639/L4 } \\
\text { G2S }\end{array}$ \\
\hline \multicolumn{2}{|l|}{ Composicão do equipamento } \\
\hline Vão inicial: & $\begin{array}{l}\text { Comprimento: } 61,30 \text { metros, com } 9 \text { tubos } \\
\text { Diâmetro: } 65 / 8 " \\
\text { Altura livre: } 3,07 \mathrm{~m}\end{array}$ \\
\hline Lance em balanço: & $\begin{array}{l}\text { Comprimento: } 27,97 \text { metros, com } 4 \text { tubos } \\
\text { Diâmetro: } 5 \% 16 " \text { ( } 2 \text { primeiros tubos) e } 4 \text { " ( } 2 \text { tubos finais) }\end{array}$ \\
\hline Canhão final: & $\begin{array}{l}\text { Vazão: } 6,0 \mathrm{~m}^{3} / \mathrm{h} \\
\text { Raio de alcance: } 15,8 \text { metros }\end{array}$ \\
\hline Número de torres: & Uma torre \\
\hline Tamanho dos pneus: & $12,4 \times 24(12,4$ "de largura da banda de rodagem $\times 24$ " de aro) \\
\hline Potência do motorredutor: & $1 \mathrm{cv}$ \\
\hline $\begin{array}{l}\text { Velocidade da última torre, com o relê } \\
\text { percentímetro regulado em } 100 \% \text { : }\end{array}$ & 180 metros por hora \\
\hline $\begin{array}{l}\text { Tempo mínimo para uma volta, com o } \\
\text { relê percentímetro regulado em } 100 \% \text { : }\end{array}$ & 2 horas e 9 minutos \\
\hline \multicolumn{2}{|l|}{ Área irrigada } \\
\hline Raio efetivo da área irrigada: & 105,07 metros \\
\hline Área circular irrigada: & 3,47 hectares \\
\hline \multicolumn{2}{|l|}{ Lâminas aplicadas e vazão } \\
\hline $\begin{array}{l}\text { Lâmina bruta aplicada } \\
\text { (relê percentímetro a } 10 \% \text { ): }\end{array}$ & $13,2 \mathrm{~mm}$ em 21 horas e 26 minutos \\
\hline Vazão necessária: & $21,35 \mathrm{~m}^{3} / \mathrm{h}$ \\
\hline $\begin{array}{l}\text { Lâmina mínima aplicada } \\
\text { (relê percentímetro a } 100 \% \text { ): }\end{array}$ & $1,32 \mathrm{~mm}$ \\
\hline Linha adutora: & $\begin{array}{l}\text { Tubo de PVC DN - } 100 \mathrm{~mm} \text { linha fixa, } 180 \text { metros de } \\
\text { comprimento }\end{array}$ \\
\hline Conjunto motobomba: & $\begin{array}{l}\text { Bomba ALBRIZZI modelo } 3048 \text { acoplado a motor BUFALO } \\
\text { de } 7,5 \mathrm{cv}, 3450 \mathrm{rpm}, 220 \mathrm{~V} \text {, trifásico }\end{array}$ \\
\hline \multicolumn{2}{|l|}{ Pressões de operação } \\
\hline Altura manométrica total: & $37,54 \mathrm{mca}$ \\
\hline Pressão no ponto do pivô: & $34,70 \mathrm{mca}$ \\
\hline Pressão na extremidade final: & $30 \mathrm{mca}$ \\
\hline $\begin{array}{l}\text { Desnivel motobomba ao ponto do } \\
\text { pivô: }\end{array}$ & $0,50 \mathrm{~m}, \mathrm{em}$ aclive \\
\hline $\begin{array}{l}\text { Desnível do ponto do pivô ao ponto } \\
\text { mais alto do terreno: }\end{array}$ & $0,0 \mathrm{~m}$ \\
\hline
\end{tabular}


adução de calda: acoplado à tubulação aérea do pivô central, conduz a calda do cabeçal de controle até o conjunto de controle automatizado da emissão de calda.

(v) conjunto de controle automatizado da emissão de calda: localizado na torre do pivô central, o qual tem a finalidade de controlar a liberação de calda a ser aplicada pelo sistema. Quando a torre está em deslocamento, ocorre a aplicação de calda, através da abertura das válvulas solenóides via acionamento do motorredutor. Quando a torre se encontra parada, as válvulas solenóides permanecem fechadas e não ocorre aplicação de calda; (vi) conjunto de emissão de calda: é o conjunto responsável pela aplicação de calda sobre a superfície do terreno ou sobre o dossel das plantas cultivadas, através de emissores do tipo microaspersor, acoplados em um tubo de polietileno de baixa densidade; (vii) conjunto de acoplamento e regulagem da altura de aplicação: acoplado na estrutura metálica do pivô central, o qual tem a finalidade de sustentar o conjunto de emissão de calda e propiciar a sua operação em diferentes alturas em relação à superfície do terreno ou do dossel das plantas cultivadas.

\subsection{Desenvolvimento do protótipo}

O protótipo foi desenvolvido tendo como referência ideológica o sistema NOTLIADA, apresentado por Dourado-Neto \& Fancelli (1999).

\subsubsection{Desenvolvimento da unidade de bombeamento e filtragem}

A unidade de bombeamento e filtragem, apresentada na Figura 4, foi instalada em um abrigo coberto, utilizando água proveniente do Rio 
Piracicaba, armazenada em um reservatório localizado na área experimental do Departamento de Produção Vegetal da ESALQ/USP. Esse reservatório também fornece água para as irrigações com o pivô central.

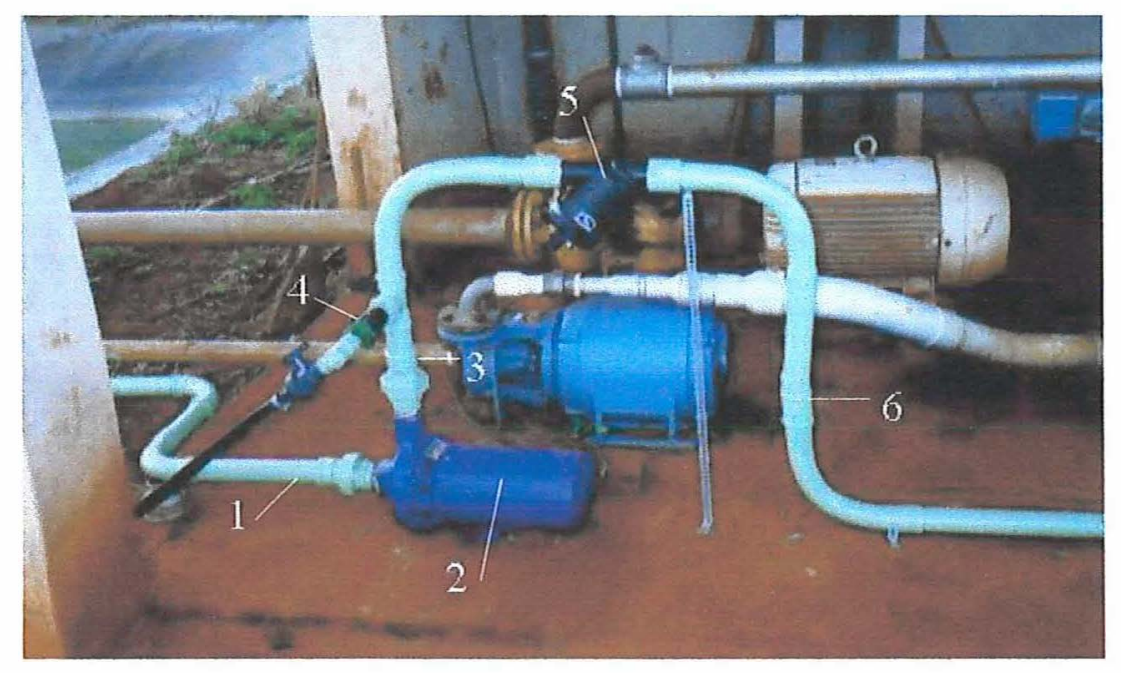

Figura 4 - Componentes da unidade de bombeamento e filtragem: (1) Tubulação e conexões de sucção em PVC Linha Fixa DN-50 mm; (2) Conjunto Motobomba KSB Hydrobloc C-3000T; (3) Conexões de saída da motobomba, em PVC roscável DN 2": (4) Sistema de recirculação contínua de água; (5) Filtro plástico de discos 120 mesh, marca AMIAD, DN 1 1⁄2"; (6) Tubulação e conexões de recalque em PVC LF $\mathrm{DN}-50 \mathrm{~mm}$.

A escolha dos componentes objetivou atender a vazão requerida pelo protótipo de 3456 litros por hora, com altura manométrica de $40 \mathrm{mca}$. A motobomba escolhida foi a KSB modelo Hydrobloc C-3000T, com motor trifásico de $3 \mathrm{cv}, 220 \mathrm{~V}$, acionado por uma chave de partida direta WEG, modelo PDW. A curva característica da motobomba, fornecida pelo fabricante, é apresentada na Figura 5. Os conjuntos de sucção e recalque são compostos por tubos e conexões de PVC com diâmetro nominal de $50 \mathrm{~mm}$, pintados com uma 
tinta especial para proteção contra intempéries, aumentando a sua vida útil (tinta marca PLASTOFLEX, modelo Vinoflex M-32, cor verde-segurança). Salienta-se que o conjunto motobomba escolhido está superdimensionado para as condições operacionais do protótipo. A adoção desse procedimento visa viabilizar o emprego da motobomba em outras atividades de pesquisa relacionadas ao protótipo a serem desenvolvidas, como também a sua utilização em sistemas de irrigação para experimentos conduzidos no Departamento de Produção Vegetal da ESALQ/USP.

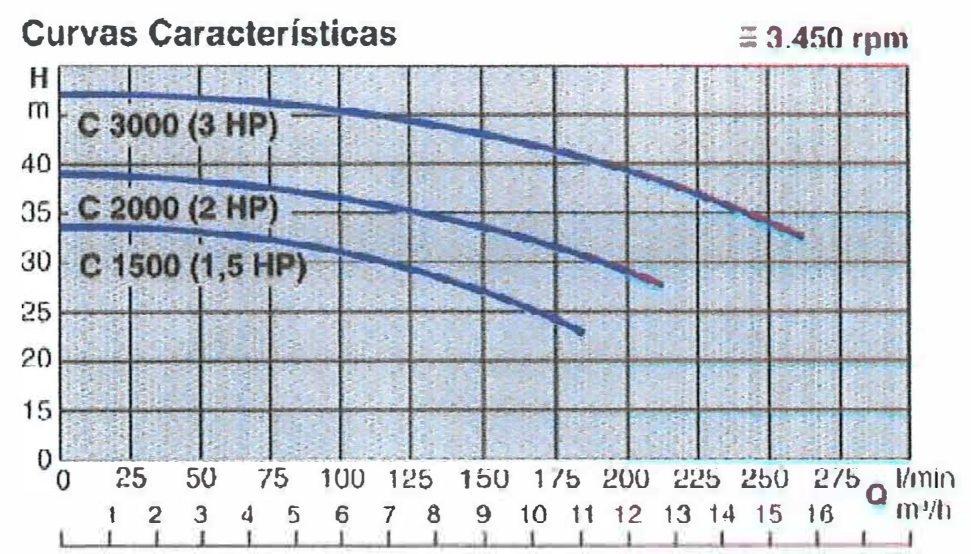

Figura 5 - Curvas características das motobombas KSB Hydrobloc, indicando a curva do modelo C 3000 (Fonte: Catálogo de produtos KSB Bombas Hidráulicas S.A).

Devido à alta concentração de algas na água, utilizou-se um filtro com elemento filtrante de discos. $\mathrm{O}$ modelo utilizado foi o filtro plástico de discos marca Amiad, modelo compacto, diâmetro nominal de 11⁄2", com elemento filtrante de 120 mesh. Segundo recomendação do fabricante ${ }^{1}$, para a vazão requerida pelo equipamento (3456 litros por hora), é possível utilizar um filtro com diâmetro nominal de 1", porém, devido à alta concentração de algas na água,

\footnotetext{
${ }^{1}$ AMIAD filtration systems. Catálogo de produtos. s.n.t.
} 
optou-se utilizar o filtro de 11/2", objetivando menores operações de limpeza ao longo do funcionamento do sistema, como também menores perdas de carga.

Conforme mencionado no item 3.2, o protótipo aplica a calda somente com o deslocamento da torre do pivô central. Quando a torre está parada, não ocorre aplicação de calda e, conseqüentemente, a motobomba irá operar com vazão nula. De acordo com Macintyre (1987) quando uma motobomba está em operação, o próprio líquido que circula pela bomba, em geral, remove o calor gerado em seu interior. Quando a bomba opera com vazões muito reduzidas ou nulas, o resfriamento pode não ser suficiente, podendo ocorrer superaquecimento causando redução da vida útil das gaxetas, dos selos mecânicos e danos aos mancais, principalmente. Para impedir que isso ocorra, as motobombas devem operar com uma descarga mínima aceitável. No geral, as motobombas apresentam em sua plaqueta metálica de identificação esse valor de vazão mínima de operação. No modelo de motobomba empregado (KSB Hydrobloc C-3000T) a vazão mínima indicada no equipamento é de $2 \mathrm{~m}^{3} / \mathrm{h}$. Para garantir essa vazão mínima no equipamento, quando a torre do pivô central estiver parada e não houver aplicação de calda, desenvolveu-se um sistema de recirculação contínua, ilustrado na Figura 6, que consiste em um bocal plástico adaptado a um regulador de pressão, que permite o retorno de parte da água bombeada, respeitando-se a vazão mínima recomendada. Os materiais empregados foram um bocal plástico cônico, marca FABRIMAR, de diâmetro $6,0 \mathrm{~mm}$, associado a um regulador de pressão FABRIMAR, modelo EXACT-40, que fornece uma pressão declarada de regulação de 28,1 mca. De acordo com informações contidas em um catálogo do fabricante $^{2}$, essa associação bocal-regulador fornece uma vazão de $2,23 \mathrm{~m}^{3} / \mathrm{h}$, valor esse um pouco acima do valor mínimo de vazão recomendado para a

\footnotetext{
${ }^{2}$ FABRIMAR S.A INDÚSTRIA E COMÉRCIO - Catálogo do Aspersor fixo AF2. s.n.t.
} 
(A)

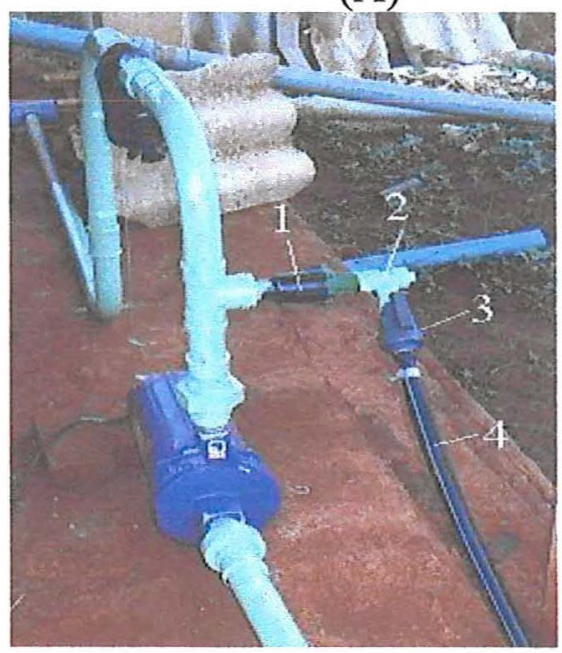

(B)

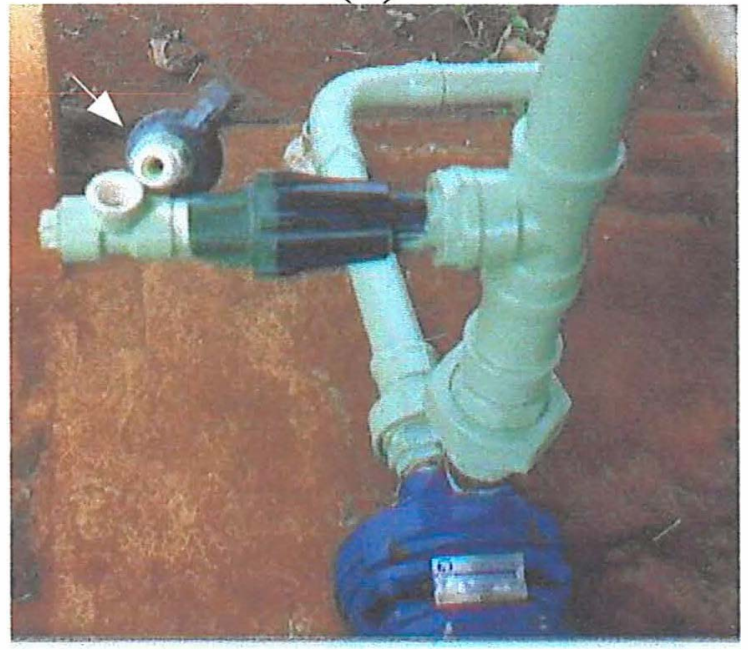

Figura 6 - Ilustração do sistema de recirculação contínua. (A) Componentes: (1) regulador de pressão FABRIMAR modelo EXACT-40; (2) conjunto de conexões em PVC de $3 / 4$, com o bocal plástico adaptado; (3) registro de esfera 3/4"; (4) Tubo de polietileno CARBORUNDUM, 20mm de diâmetro interno. (B): Detalhe do bocal plástico cônico FABRIMAR, diâmetro 6,0mm, adaptado em nípel roscável de PVC de 1/2”.

motobomba, porém adotado no sistema como uma margem de segurança. A ligação do bocal ao regulador de pressão foi feita adaptando-se o bocal no interior de conexões de PVC roscável. Para conduzir a água do conjunto até o reservatório foram empregados 6 metros de tubo de polietileno de baixa densidade, marca CARBORUNDUM, com $20 \mathrm{~mm}$ de diâmetro interno. O sistema de recirculação contínua apresenta o inconveniente de obrigar a motobomba a trabalhar continuamente com uma vazão acima da necessária para a operação do protótipo, porém, devido à baixa potência da motobomba, esse sistema torna-se viável, quando comparado aos sistemas de recirculação automática apresentados por Macintyre (1987), que empregam válvulas especiais, cujos custos somente viabilizam a sua utilização em grandes sistemas de recalque. 


\subsubsection{Linha de adução de água}

Para conduzir a água da unidade de bombeamento e filtragem até o cabeçal de controle foi utilizada a linha adutora em PVC linha fixa de $100 \mathrm{~mm}$ de diâmetro, que conduz a água de irrigação do pivô central. Através da abertura e fechamento de registros (Figura 7), a água da unidade de bombeamento é desviada para a adutora e, no ponto do pivô, a água recalcada é desviada para a aplicação de produtos químicos através de um registro localizado no cabeçal de controle.

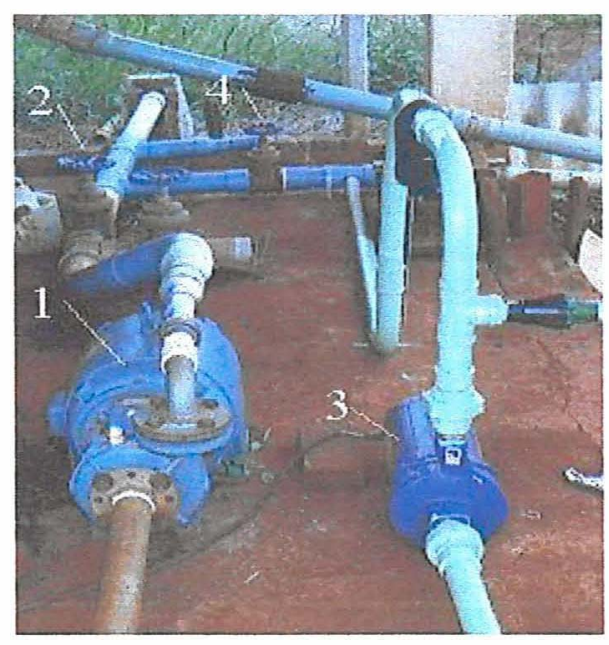

Figura 7 - Conjunto de registros empregados na ligação da unidade de bombeamento na linha de adução de água: (1) motobomba para irrigação com pivô central; (2) registro de saída da motobomba do pivô central; (3) unidade de bombeamento do protótipo; (4) registro de saída da unidade de bombeamento do protótipo.

O funcionamento do conjunto de registros, ilustrado na Figura 7, ocorre da seguinte forma: quando (1) está operando, (2) está aberto e (4) está fechado; quando (3) está operando, (2) está fechado e (4) está aberto.

A utilização da adutora do pivô central para a condução de água para o protótipo apresenta a vantagem de reduzir os custos de investimento com 
equipamentos, dispensando a instalação de uma nova adutora, como também a redução dos custos operacionais com energia, devido às reduzidas perdas de carga resultantes da baixa vazão conduzida em uma tubulação de grande diâmetro. Porém, para se adotar essa alternativa, deve-se instalar um sistema de filtragem complementar no cabeçal de controle para evitar a obstrução dos emissores com detritos provenientes de incrustações no interior das paredes dos tubos, como também filtrar a água que fica armazenada na tubulação após as irrigações com o pivô central.

\subsubsection{Desenvolvimento e componentes do cabeçal de controle}

O cabeçal de controle, ilustrado na Figura 8, tem como finalidade realizar uma nova filtragem da água e injetar os produtos químicos formando a calda a ser aplicada.

\subsubsection{Registros de gaveta de 4"}

Tem por objetivo interromper o fluxo de água para o pivô central, possibilitando a alimentação de água ao cabeçal de controle. 


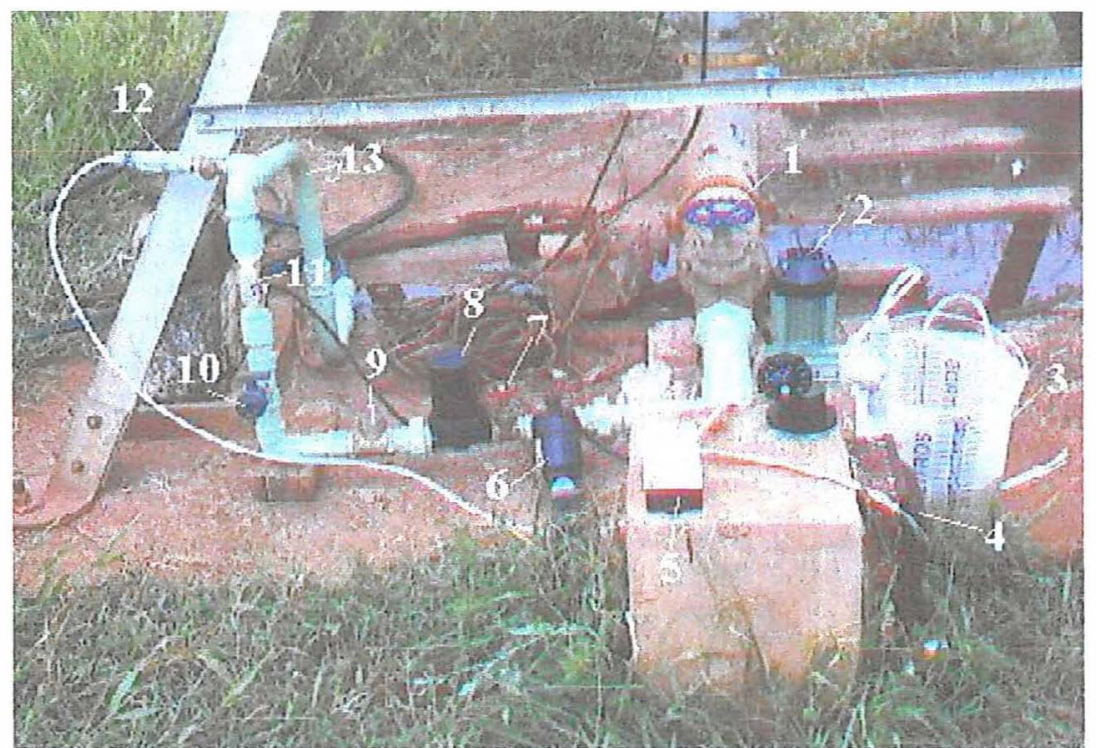

Figura 8 - Ilustração do cabeçal de controle: (1) registro de gaveta de 4"; (2) bomba dosadora de produtos químicos; (3) reservatório para produtos químicos; (4) chave geral de energia elétrica; (5) chave de partida da bomba dosadora; (6) conjunto de fornecimento de água; (7) registro de gaveta de 11/2"; (8) filtro de discos MAC-LOREN; (9) válvula de retenção de 11/2"; (10) Registro de drenagem; (11) válvula de fluxo KSB hidroflow; (12) ponto de injeção de produtos químicos; (13) conjunto de conexões e tubos de PVC.

\subsubsection{Registro de gaveta de $1 \frac{1}{2}$ "}

Controla o fluxo de água para o cabeçal de controle.

\subsubsection{Filtro de discos de 11/2"}

Tem como finalidade reter impurezas provenientes de incrustações no interior da tubulação adutora, como também da água retida na adutora após as 
irrigações com o pivô central, foi instalado no cabeçal de controle um filtro de 11/2", com elemento filtrante de discos de 120mesh, da marca MAC-LOREN.

\subsubsection{Bomba dosadora}

A bomba dosadora realiza a injeção dos produtos químicos na água. $\mathrm{Na}$ escolha desse sistema, procurou-se um equipamento que permitisse a utilização de baixos volumes, possibilitando a injeção de produtos puros ou com pequena diluição, dispensando a instalação de reservatórios de pré-mistura, contribuindo para uma maior economicidade do protótipo e na segurança para os operadores e ao meio ambiente. Foi escolhida a bomba dosadora da marca SODISCIENTIFICA, de fabricação italiana, apresentada na Figura 9, cujas principais características técnicas estão descritas na Tabela 2. Esse equipamento apresenta elevada precisão de dosagem, facilidade de operação e reduzido consumo de energia. A dosagem e injeção do produto é executada através de um pistão cerâmico, associado a um conjunto de válvulas de esfera, acionados por um motor elétrico trifásico de $0,12 \mathrm{cv}, 220 \mathrm{~V}$. A máxima vazão que o sistema injeta é de 54 litros por hora. A regulagem é feita através da variação do comprimento de curso do pistão, girando-se manualmente o disco graduado (Figura 9). A vazão injetada é indicada no disco graduado com uma escala que varia de 0 (zero) a 10, com subdvisões de 0,2 , que correspondem respectivamente de 0 a $100 \%$ da vazão máxima, com subdivisões de $2 \%$. De acordo com o fabricante ${ }^{3}$, o intervalo útil de regulagem é de 1 a 10 (10 a 100\%), onde é garantida a precisão de regulagem de $1 \%$ da vazão máxima ( 0,54 litros por hora). A máxima pressão na rede hidráulica, na qual a bomba injeta os produtos químicos com precisão, é de 10 bar.

\footnotetext{
${ }^{3}$ SODI SCIENTÍFICA - ENVIRONMENTO DIVISION. Metering pumps "PD" series user's manual. Florence: s. ed., 1995, 27p.
} 


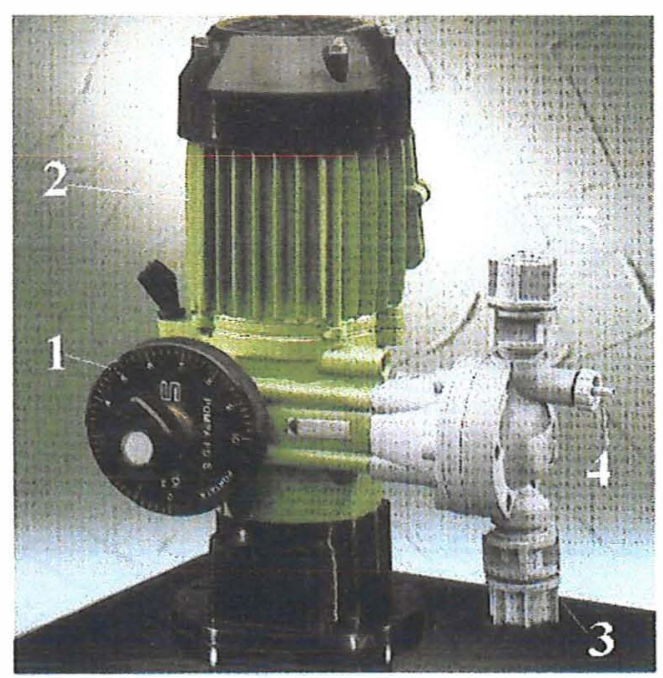

Figura 9 - Ilustração da bomba dosadora SODI-SCIENTIFICA modelo PD S: (1) disco graduado para regulagem de vazão; (2) Motor elétrico, $220 \mathrm{~V}$, trifásico, potência $0,12 \mathrm{cv}$; (3) conexões de suç̧ão de produtos químicos; (4) ponto de amostragem de produtos químicos; (5) conexões de saída de produtos químicos a serem injetados.

Tabela 2 - Características técnicas gerais da bomba dosadora SODISCIENTÍFICA modelo PD S.

\begin{tabular}{|l|l|}
\hline Dimensões & $315 \mathrm{~mm}$ \\
\hline Altura: & $250 \mathrm{~mm}$ \\
\hline Largura (valor máximo): & $5,8 \mathrm{~kg}$ \\
\hline Peso bruto: & Polipropileno reforçado com fibra de vidro \\
\hline Materiais & Cerâmica \\
\hline Cabeça, válvulas e conexões: & Polietileno com $10 \mathrm{~mm}$ de diâmetro \\
\hline Pistão: & Metal liga leve \\
\hline Mangueiras: & \multicolumn{2}{|l|}{} \\
\hline Corpo da bomba: & $27 \mathrm{~mm}$ \\
\hline Características construtivas & $10 \mathrm{~mm}$ \\
\hline Diâmetro do pistão: & 162 pulsos por minuto \\
\hline Curso do pistão: & Assíncrono trifásico, 220V; potência $0,12 \mathrm{cv}$ \\
\hline Freqüência mínima de pulsos: & \\
\hline Motor: & 5,4 litros por hora \\
\hline Características de performance & 54 litros por hora \\
\hline Vazão mínima: & $1 \%$ da vazão máxima \\
\hline Vazão máxima: & $10 \mathrm{bar}$ \\
\hline Precisão de dosagem: & \\
\hline Pressão máxima para injeção: &
\end{tabular}




\subsubsection{Válvula de fluxo}

A válvula de fluxo utilizada é da marca $\mathrm{KSB}$, modelo Hydroflow, ilustrada na Figura 10. Tem como função interromper o funcionamento da bomba dosadora quando não há fluxo de água no sistema, seja pelas paradas da torre, fechamento do registro de $1 \frac{1}{2}$ " ou interrupção no funcionamento da unidade de bombeamento e filtragem. Com isso, não ocorre variação na concentração da calda aplicada e desperdício de produtos químicos, o que contribui para evitar problemas de fitotoxidade e contaminações ao meio ambiente. Seu funcionamento é baseado em um sistema eletromagnético, onde um imã em forma de disco, instalado no interior da peça, é erguido pelo fluxo da água e fecha o contato elétrico. Quando não há fluxo de água, o imã permanece na parte inferior da válvula e o contato elétrico não ocorre.

\subsubsection{Chave geral de energia elétrica e chave de partida da bomba dosadora}

A chave geral de energia elétrica controla o fornecimento de energia elétrica para a bomba dosadora.

A chave de partida da bomba dosadora possui uma chave seletora de duas posições: manual e auto. Na posição manual, a bomba dosadora é acionada somente pela chave geral de energia elétrica. $\mathrm{Na}$ posição auto a bomba dosadora é acionada pela ação da válvula de fluxo. A opção de operação manual é empregada quando estamos preparando a bomba dosadora para uma aplicação de produtos químicos e a posição auto é utilizada quando o protótipo está em operação. 


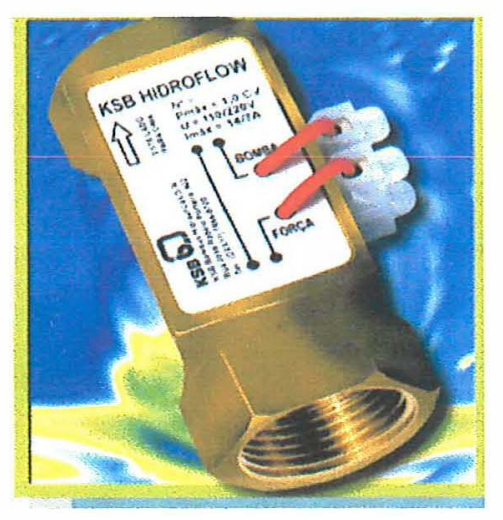

Figura 10 - Ilustração da válvula de fluxo KSB Hidroflow, com conexões de entrada e saída de l".

\subsubsection{Válvula de retenção de 11/2"}

A válvula de retenção de $1 \frac{1}{2}$ " foi instalada antes do ponto de injeção de produtos químicos, de modo a impedir o refluxo de calda para a água, aumentando a segurança ao meio ambiente.

\subsubsection{Conjunto de fornecimento de água}

O conjunto de fornecimento de água é composto por um filtro de discos de 1" AMIAD (malha 120 mesh) e um registro de esfera plástico de 3/4". Visa o abastecimento de água para a diluição dos produtos químicos ou utilização de emergência em caso de contato dos produtos químicos tóxicos pelo operador.

\subsubsection{Registro de drenagem}

O registro de drenagem promove o esvaziamento de água ou calda do sistema de adução de calda, em operações de limpeza do sistema. 


\subsubsection{Ponto de injeção de produtos químicos}

O ponto de injeção de produtos químicos é composto por conexões de PVC roscável; um conjunto de conexões especiais de injeção da bomba dosadora e uma válvula de retenção de 3/4", instalada de forma a impedir a saída de água da tubulação e permitir a injeção de produtos químicos pela bomba dosadora.

\subsubsection{Conjunto de conexões e tubos de PVC}

O conjunto de conexões e tubos de PVC promove o fluxo de água e calda no cabeçal. Foram pintados com tinta especial marca PLASTOFLEX, modelo Vinoflex M-32, para proteção contra a ação de intempéries, aumentando a sua vida útil.

\subsubsection{Desenvolvimento e componentes do sistema de adução de calda}

O sistema de adução de calda tem como finalidade conduzir a calda do cabeçal de controle até os conjuntos de emissão de calda.

\subsubsection{Conjunto de acoplamento do cabeçal de controle a tubulação aérea}

O conjunto de acoplamento do cabeçal de controle a tubulação aérea, ilustrado na Figura 11, realiza a condução de calda do cabeçal de controle a tubulação aérea do protótipo. É composto por um tubo de polietileno CARBORUNDUM de $26 \mathrm{~mm}$ de diâmetro interno e 12 metros de comprimento, 
tendo conectado em suas extremidades conexões de PVC engate rápido roscável de $50 \mathrm{~mm}$ de diâmetro nominal. A escolha do tubo de polietileno foi devido a sua grande flexibilidade e facilidade de manuseio.

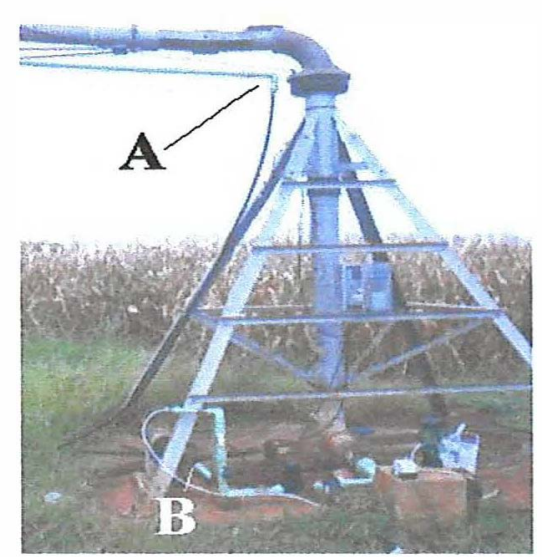

Figura 11 - Ilustração do conjunto de acoplamento do cabeçal de controle a tubulação aérea: (A) conexão no tubo de PVC 50 mm linha fixa; (B) conexão de saída do cabeçal de controle.

Antes de colocar o protótipo em operação, deve-se engatar o tubo no cabeçal de controle (item B, Figura 11), contorná-lo ao redor da torre do ponto do pivô, no sentido oposto ao qual o equipamento vai se deslocar e, finalmente, conectá-lo na tubulação aérea (item A, Figura 11). Esse procedimento possibilita que o tubo de polietileno se desenrole conforme o pivô se desloca, sem causar qualquer tipo de tração no tubo que danifique os componentes do cabeçal de controle e da tubulação aérea. Após a aplicação, o tubo de polietileno deve ser desacoplado e quando houver outra aplicação, o procedimento deve ser repetido. Para as operações de acoplamento do tubo de polietileno na tubulação aérea, podem ser empregados os degraus da torre no ponto do pivô como meio de acesso. 


\subsubsection{Tubulações aéreas de adução de calda}

As tubulações aéreas de adução de calda são de PVC linha fixa soldável, com $50 \mathrm{~mm}$ de diâmetro nominal e classe de pressão PN 80. Partindo-se do ponto do pivô até a sua extremidade final foram instalados 88 metros de tubulação. Os tubos foram pintados com a tinta especial PLASTOFLEX, modelo Vinoflex M-32, cor verde-segurança, para proteção contra intempéries. A Figura 12 mostra esquematicamente as tubulações instaladas. Para facilitar a drenagem da tubulação nas operações de manutenção e limpeza, foram utilizadas duas válvulas antivácuo plásticas da marca MAC-LOREN, com conexão roscável de 1", ficando uma válvula instalada antes do conjunto de controle automatizado da emissão de calda e outra na extremidade final da tubulação. $\mathrm{O}$ acoplamento dos tubos de PVC na tubulação aérea do pivô foi feito com braçadeiras especiais, apresentadas esquematicamente na Figura 13. O primeiro tipo (item A, Figura 13), foi fabricado com aço chato galvanizado, de $1 / 2$ " de largura e $1 / 8$ " de espessura e o segundo tipo (item B, Figura 13) feito com fitas metálicas flexíveis, em aço galvanizado, com 3/4" de largura, perfuradas com furos de $1 / 4$ " espaçados em $3 / 8$ ". Ambos os modelos foram moldados em sua parte superior de forma a contornar as tubulações aéreas do pivô com diâmetros de 6\%" (vão inicial), 5\%16" e 4" (lance em balanço), e em sua parte inferior moldados para abraçar os tubos de PVC. Ambos os modelos separam o tubo de PVC da tubulação aérea do pivô central em uma distância de $0,15 \mathrm{~m}$, com a finalidade de desviar das flanges dos tubos e das chapas de aço que formam a estrutura do pivô. As braçadeiras foram instaladas espaçadas de 3 em 3 metros, intercalando-se o modelo de aço chato com o modelo de fita flexível. As braçadeiras de aço chato, por serem rígidas, realizam a sustentação do peso do tubo e impedem o seu deslocamento durante o caminhamento do pivô. As abraçadeiras de fita de aço flexível realizam somente a sustentação do peso da tubulação. 
(A)

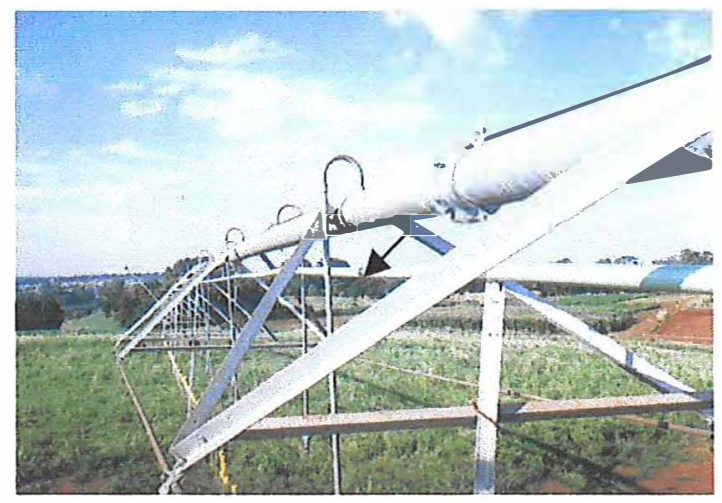

(B)

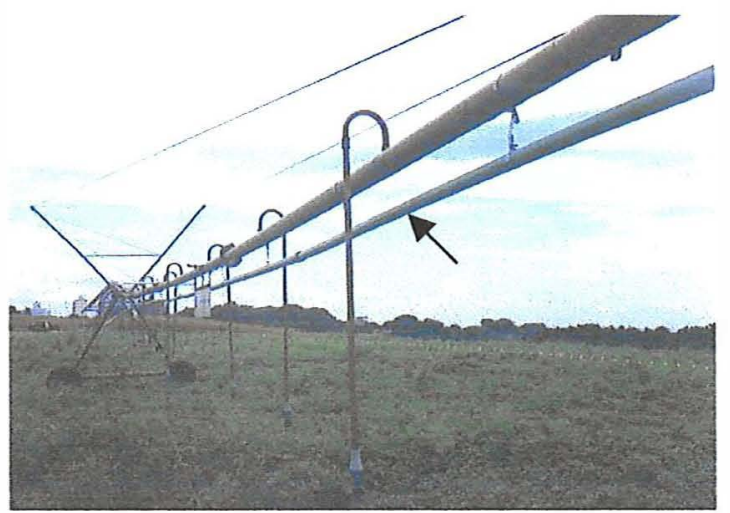

Figura 12 - Tubulações aéreas do sistema de adução de calda: (A) primeiro vão do pivô; (B) lance em balanço.

(a)

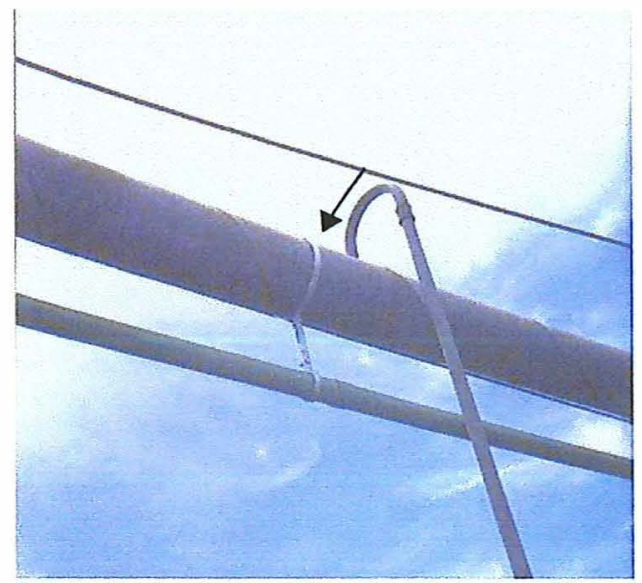

(b)

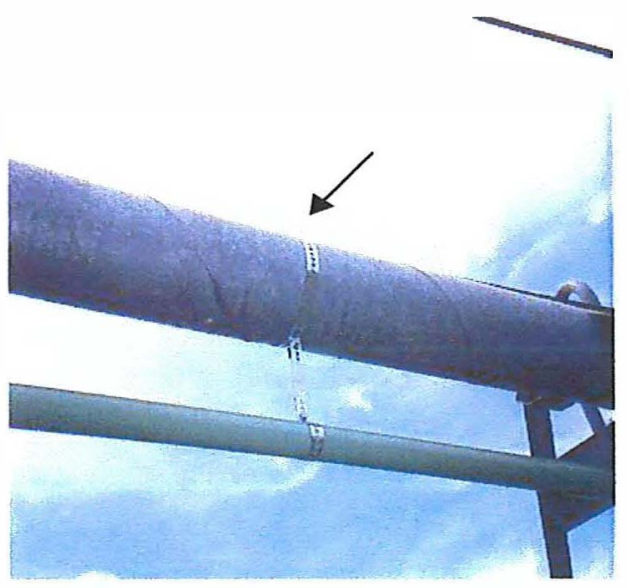

Figura 13 - Braçadeiras do sistema de adução de calda: (a) braçadeira de aço chato galvanizado, (b) braçadeira de aço flexível galvanizado

3.3.5 Desenvolvimento do conjunto de controle automatizado da emissão de calda

O conjunto de controle automatizado da emissão de calda, apresentado na Figura 14, está localizado na torre do pivô central, instalado no 
tubo de PVC do conjunto de adução de calda, e controla o fornecimento de calda para o conjunto de emissão de calda. Seu funcionamento se dá através da ação de válvulas solenóides ligadas ao sistema elétrico do motorredutor, ocorrendo a aplicação de calda somente quando ocorre o deslocamento da torre móvel. Foram empregadas válvulas solenóides especiais, da marca ASCOVAL, modelo 8210D95, voltagem $220 \mathrm{~V}$, corrente alternada, freqüência $60 \mathrm{~Hz}$, operando de modo normalmente fechado, ou seja, somente abrem e permitem o fluxo da água quando recebem corrente elétrica. Devido ao pequeno diâmetro de suas conexões de entrada e saída (3/4"), foram utilizadas duas válvulas operando em paralelo, ocasionando menores perdas de carga. O emprego desse modelo de válvula solenóide se justifica pela sua grande resistência a operações intermitentes de acionamento. Segundo um de seus distribuidores ${ }^{4}$, esse modelo tem sido utilizado em sistemas com intermitências de acionamento na ordem de um-dois acionamentos por segundo, em aplicações na indústria química. No caso do pivô central utilizado, onde a freqüência de acionamentos é de um acionamento por minuto, o distribuidor prevê uma vida útil da válvula solenóide de aproximadamente dez anos. As válvulas solenóides geralmente utilizadas na automação de sistemas de irrigação localizada, com voltagem de operação de $24 \mathrm{~V}$, corrente alternada, não foram projetadas para suportar acionamentos intermitentes e por isso não foram utilizadas.

\subsubsection{Desenvolvimento do conjunto de emissão de calda.}

\subsubsection{Descrição geral}

O conjunto de emissão de calda, ilustrado na Figura 15, é responsável pela aplicação da calda na superfície do solo ou sobre o dossel das plantas. É composto por microaspersores, que realizam a emissão da calda; por

\footnotetext{
${ }^{4}$ C.E.K automatização Ltda, Sorocaba, SP, 1999 (comunicação pessoal)
} 
tubos de polietileno, que conduzem a calda aos microaspersores, e por reguladores de pressão, que possibilitam o funcionamento do conjunto com pressão constante e estável, contribuindo para uma aplicação uniforme de calda. O conjunto de emissão de calda é acoplado no protótipo por meio do conjunto de acoplamento e regulagem da altura de aplicação, que será abordardado no próximo tópico.

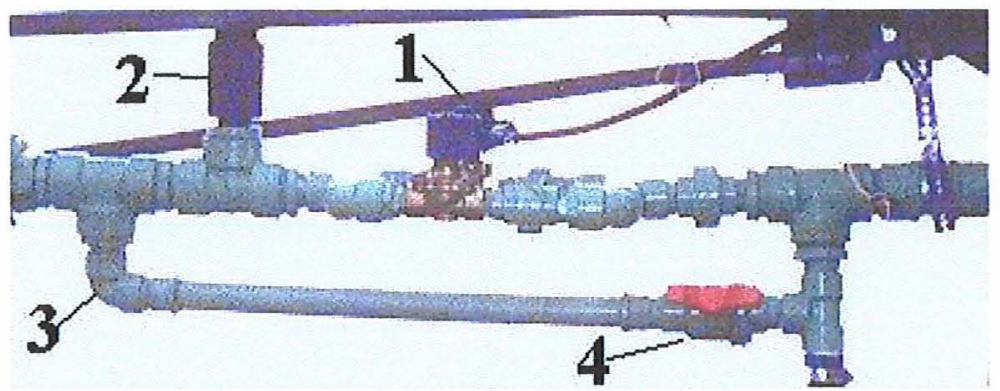

Figura 14 - Ilustração do conjunto de controle automatizado da emissão de calda: (1) válvulas solenóides ASCO; (2) válvula antivácuo MAC-LOREN; (3) conjunto de conexões em PVC; (4) registro de esfera de 1" para controle manual do fluxo de água.

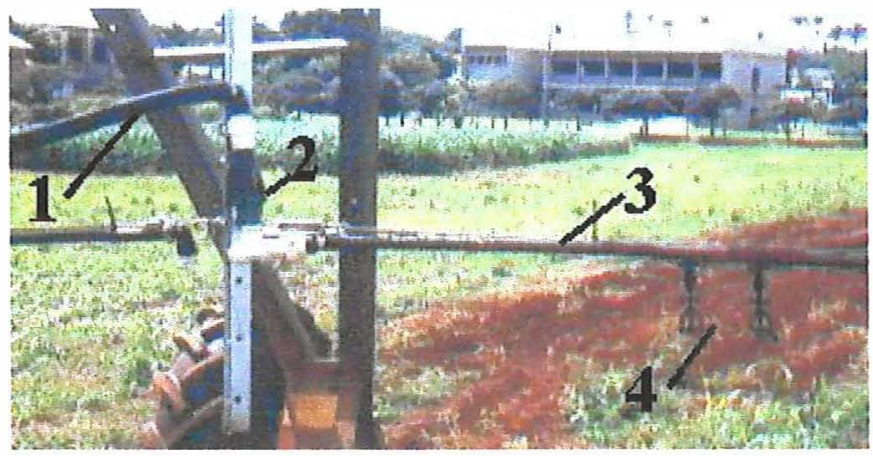

Figura 15 - Componentes do conjunto de emissão de calda: (1) tubo de polietileno, $26 \mathrm{~mm}$ de diâmetro interno; (2) válvula reguladora de pressão FABRIMAR, modelo EXACT-30; (3) tubo de polietileno, $20 \mathrm{~mm}$ de diâmetro; (4) microaspersores CARBORUNDUM, modelo multifunção. 


\subsubsection{Características técnicas do microaspersor e componentes auxiliares}

Diversos tipos de emissores podem ser empregados no conjunto de emissão, como por exemplo, os bicos utilizados nos sistemas tratorizados de pulverização. Preferimos utilizar no protótipo emissores do tipo microaspersor, devido ao seu menor custo quando comparado aos bicos, como também para melhor conhecer as suas características operacionais em condições de campo.

O microaspersor utilizado é da marca CARBORUNDUM, modelo multifunção. Devido ao microaspersor ser instalado no protótipo de forma invertida, empregou-se a bailarina modelo "verde", recomendada para essa finalidade, de acordo com o catálogo do produto ${ }^{5}$. A Tabela 3 apresenta as características técnicas do microaspersor. A relação vazão-pressão do emissor é expressa pela seguinte equação:

$$
q=a \cdot H^{b}
$$

em que: $q$ é a vazão do microaspersor em litros por hora (L/h); $H$ é a pressão de operação do microaspersor em quilograma força por centímetro quadrado $\left(\mathrm{kgf} / \mathrm{cm}^{2}\right) ; a$ é um coeficiente de ajuste da equação, de dimensão $(\mathrm{L} / \mathrm{h}) \cdot\left(\mathrm{cm}^{2} / \mathrm{kgf}\right)^{\mathrm{b}}$, apresentado na Tabela 3 e $b$ é o expoente de fluxo do emissor, adimensional, apresentado da Tabela 3.

Os microaspersores são emissores que foram concebidos para aplicação pontual de água. Para ser utilizado em um sistema com aplicação uniforme de água, devemos empregar um espaçamento entre microaspersores na linha que permita uma boa sobreposição da água. De acordo com o fabricante ${ }^{6}$, o máximo espaçamento entre microaspersores para essa finalidade deve ser de aproximadamente $50 \%$ do diâmetro molhado pelo emissor. Dessa forma, foram

\footnotetext{
${ }^{5}$ CARBORUNDUM IRRIGAÇÃO. Catálogo do microaspersor multifunção. s.n.t.

${ }^{6}$ CARBORUNDUM IRRIGAÇÃO - Departamento de engenharia de aplicação. Comunicação pessoal, 2000.
} 
estabelecidos os espaçamentos máximos entre microaspersores no conjunto de emissão de calda, apresentados na Tabela 3.

Em cada microaspersor, foi utilizada uma válvula antigota, da marca DAN SPRINKLERS, denominada de "L.P.D." Reakage prevention device), modelo "STANDARD". Para conectar o microaspersor na válvula antigota e no tubo de polietileno, foi empregada a conexão especial, fabricada

Tabela 3 - Dados técnicos do microaspersor CARBORUNDUM multifunção: cor e diâmetro dos bocais; vazão dos bocais em diferentes pressões; diâmetro molhado pelo microaspersor operando invertido a $0,40 \mathrm{~m}$ de altura com a bailarina verde na pressão de $15 \mathrm{mca}$; máximo espaçamento entre emissores na linha; parâmetros da equação vazãopressão (Equação 1).

\begin{tabular}{|c|c|c|c|c|c|c|c|c|c|c|}
\hline \multicolumn{2}{|c|}{ Bocal } & \multirow{2}{*}{\multicolumn{5}{|c|}{$\frac{\text { Vazão (litros/hora) }}{\text { Pressão (mca) }}$}} & \multirow{3}{*}{$\begin{array}{c}\text { Diâmetro } \\
\text { molhado (m); } \\
\text { Bailarina } \\
\text { verde; } \\
0,40 \text { m altura; } \\
\text { pressão } \\
15 \text { mca }\end{array}$} & \multirow{3}{*}{$\begin{array}{c}\text { Máximo } \\
\text { espaçamento } \\
\text { entre } \\
\text { emissores na } \\
\text { linha } \\
\text { (metros) }\end{array}$} & \multirow{2}{*}{\multicolumn{2}{|c|}{$\begin{array}{l}\text { Parâmetros da } \\
\text { Equação (1) }\end{array}$}} \\
\hline \multirow[b]{2}{*}{ Cor } & \multirow[b]{2}{*}{$\begin{array}{l}\text { Diâmetro } \\
\text { (mm) }\end{array}$} & & & & & & & & & \\
\hline & & 1,0 & 1,5 & 2,0 & 2,5 & 3,0 & & & $a$ & $b$ \\
\hline grafite & 0,80 & 25 & 31 & 36 & 40 & 45 & 5,8 & 2,7 & 7,2758 & 0,5352 \\
\hline preto & 0,90 & 27 & 36 & 42 & 47 & 51 & 5,9 & 3,0 & 8,2441 & 0,5296 \\
\hline Verde claro & 1,00 & 34 & $\overline{43}$ & 50 & 56 & 61 & 6,6 & 3,3 & 9,9509 & 0,5373 \\
\hline bege & 1,10 & 41 & 47 & 55 & 63 & 69 & 6,9 & 3,5 & 10,2610 & 0,5578 \\
\hline branco & $\overline{1,14}$ & 48 & 54 & 64 & 77 & 88 & 7,1 & 3,6 & 14,1840 & 0,5000 \\
\hline Amarelo & 1,20 & 57 & 64 & 77 & 90 & 96 & 7,4 & 3,7 & 16,3070 & 0,5001 \\
\hline marrom & 1,30 & 61 & 74 & 86 & 98 & 106 & 7,6 & 3,8 & 18,2464 & 0,4991 \\
\hline Roxo & 1,40 & 66 & 80 & 94 & 108 & 118 & 7,8 & 3,9 & 19,5410 & 0,5113 \\
\hline Verde & 1,50 & 72 & 90 & 101 & 120 & 128 & 8,3 & 4,2 & 22,4540 & 0,5078 \\
\hline Rosa & 1,60 & 78 & 96 & 110 & 125 & 136 & 8,8 & 4,4 & 22,9180 & 0,5197 \\
\hline Laranja & 1,80 & 90 & 115 & 128 & 139 & 150 & 8,9 & 4,5 & 28,8040 & 0,4997 \\
\hline
\end{tabular}

Fonte: CARBORUNDUM IRRIGAÇÃO. Catálogo do microaspersor multifunção. s.n.t.

CARBORUNDUM IRRIGAÇÃO - Departamento de engenharia de aplicação. Comunicação pessoal, 2000. 
pela DAN SPRINKLERS, denominada de "butterfly barb". A ilustração desses componentes é apresentada na Figura 16. A válvula antigota opera de forma a permitir o fluxo de água para o microaspersor somente quando a pressão na tubulação é superior a $10 \mathrm{mca}$, isso contribui para a imediata paralisação da aplicação de calda pelos microaspersores, quando a torre do pivô para de caminhar e o fornecimento de calda é interrompido, como também possibilita a rápida pressurização da rede quando a torre volta a caminhar e a calda pressurizada é liberada.

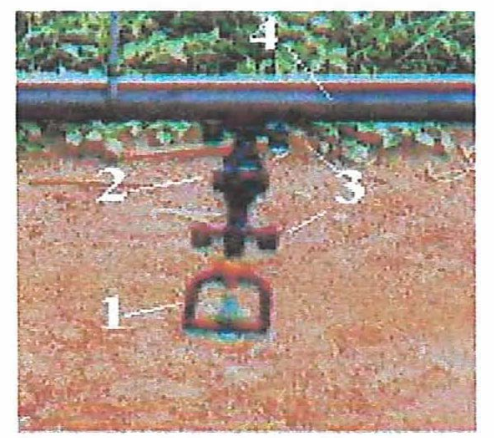

Figura 16 - Ilustração: (1) do microaspersor CARBORUNDUM modelo multifunção; (2) da válvula antigota L.P.D., marca DANSPRINKLERS, modelo "standard"; (3) dos conectores especiais "butterfly barb", marca DAN SPRINKLERS; (4) do tubo de polietileno com $20 \mathrm{~mm}$ de diâmetro interno.

\subsubsection{Características técnicas da válvula reguladora de pressão}

O regulador de pressão empregado no conjunto de emissão de calda é da marca FABRIMAR, modelo EXACT-30, com pressão declarada de regulação de $30 \mathrm{psi}$ (21mca). Esse tipo de válvula reguladora opera de forma a reduzir uma pressão de entrada para uma pressão de saída, de valor determinado em função do modelo do regulador. A pressão de saída varia de acordo com a 
vazão, diminuindo na medida em que a vazão que flui pela válvula aumenta. A pressão de entrada exerce pequeno efeito na pressão de saída, dentro dos limites operacionais da válvula, recomendados pelo fabricante ${ }^{7}$. Com base nessas informações, realizou-se um ensaio no Laboratório de Hidráulica do Departamento de Engenharia Rural da ESALQ/USP, determinando-se as pressões de saída para a válvula utilizada com vazões variando de 501 a $2004 \mathrm{~L} / \mathrm{h}$, na pressão de entrada de $35 \mathrm{mca}$, valores esses representativos das condições operacionais do protótipo. No ensaio foram utilizados os seguintes instrumentos: dois manômetros digitais com escala de $0,00-10,00 \mathrm{kgf} / \mathrm{cm}^{2}$ e precisão de $0,01 \mathrm{kgf} / \mathrm{cm}^{2}$, um medidor de vazão magnético indutivo com precisão de $1 \%$ e um conjunto motobomba. Os resultados do ensaio estão apresentados na Tabela 4.

Tabela 4 - Pressões de saída (mca) medidas para diferentes vazões $(\mathrm{L} / \mathrm{h})$ com a válvula reguladora de pressão FABRIMAR, modelo EXACT-30, na pressão de entrada de 35 mca.

\begin{tabular}{|c|c|c|c|c|}
\hline Vazão (L/h) & 501,0 & 976,9 & 1462,9 & 2004,0 \\
\hline Pressão de saída (mca) & 22,8 & 22,7 & 22,6 & 22,5 \\
\hline
\end{tabular}

Observando os valores da Tabela 4 verifica-se que a pressão de saída variou muito pouco com a vazão, assim utilizou-se nos dimensionamentos o valor constante de $22,5 \mathrm{mca}$, representativo das condições operacionais do protótipo.

\footnotetext{
7 FABRIMAR IRRIGAÇÃO. Boletim Técnico $01 / 2000$ - Determinação das curvas de desempenho dos reguladores de pressão FABRIMAR modelos EXACT-10; EXACT-15 E EXACT-20. Rio de Janeiro. 2000. 26p.
} 


\subsubsection{Metodologia para as estimativas das perdas de carga.}

As estimativas das perda de carga por atrito nos tubos de polietileno foram feitas através da equação de Darcy-Weisbach com "f" de Blasius, apropriada para essa finalidade, conforme verificado por Botrel (1984):

$$
h f=7,8048 \cdot 10^{-4} \cdot Q^{1,75} \cdot D^{-4,75} . L
$$

em que: $h f$ é a perda de carga, em mca; $Q$ é a vazão em $\mathrm{m}^{3} / \mathrm{s} ; D$ é o diâmetro da tubulação (m) e $L$ é o comprimento da tubulação (m).

Para computar a perda de carga localizada causada pela inserção do microaspersor no tubo de polietileno, foram utilizados os comprimentos virtuais equivalentes a essa perda de carga, determinados por Botrel (1984).

\subsubsection{Diferenças de nível do terreno e cotas de localização dos microaspersores}

Foram medidas no campo através de um nível de precisão.

\subsubsection{Cálculo da vazão necessária aos microaspersores}

No cálculo da vazão a ser aplicada pelos microaspersores no conjunto de emissão de calda, deve-se considerar a sua posição em relação ao ponto do pivô central, pois conforme o emissor vai se distanciando desse, maior passa a ser a sua vazão, pois gradualmente necessita-se aplicar a calda em áreas cada vez maiores. A área representativa na qual um microaspersor aplica a calda é expressa pela seguinte equação:

$$
A i=\pi \cdot\left[(D i+E S P i / 2)^{2}-(D i-E S P i / 2)^{2}\right]
$$


em que $\mathrm{A}_{i}$ é a área $\left(\mathrm{m}^{2}\right)$ representativa do i-ésimo microaspersor; $D i$ é a distância (m) deste em relação ao ponto do pivô (m), e ESPi é o espaçamento entre microaspersores $(\mathrm{m})$, correspondente ao i-ésimo microaspersor.

Pela equação (3), a área $A i$ é a área compreendida pelo círculo de raio $(D i+E S P i / 2)$ e o círculo de raio $(D i-E S P i / 2)$.

O volume de água a ser aplicado é calculado por:

$$
V i=A i . L n
$$

em que Vi é o volume de água (L) aplicado pelo i-ésimo microaspersor, $L n$ é a lâmina (mm) de calda a ser aplicada.

A vazão de calda a ser aplicada pelo microaspersor é então calculada pela seguinte expressão:

$$
Q i=V i / T o
$$

em que $Q i$ é a vazão $(\mathrm{L} / \mathrm{h})$ do i-ésimo microaspersor e To é o tempo de operação do pivô central para percorrer a área $A i$.

Para determinar o espaçamento entre microaspersores e suas respectivas vazões foi adotado o seguinte procedimento iterativo, realizado com o auxílio de planilha eletrônica: 1) através das equações (3), (4) e (5), foi calculada a vazão necessária para microaspersores teoricamente espaçados em $0,5 \mathrm{~m}$ em toda a extensão do raio do pivô, para aplicar uma determinada lâmina de calda; 2) com os dados do passo 1 e com as informações referentes a vazão e espaçamento máximo entre microaspersores, contidos na Tabela 3, foi-se gradualmente somando as vazões nos trechos de $0,5 \mathrm{~m}$ até encontrar um valor de vazão e espaçamento entre microaspersores (multiplo de $0,5 \mathrm{~m}$ ), compatível para operar com alguns bocais comerciais disponíveis, e assim sucessivamente até completar toda a extensão do raio do pivô central; 3) caso o valor de lâmina de calda adotado no passo 1 não possibilitasse o emprego dos bocais disponíveis na quase totalidade do raio do pivô, um novo valor de lâmina de calda era adotado e os 
passos 1 e 2 repetidos; 4) quando encontrada uma série teórica de dados de vazão e espaçamento entre microaspersores, o processo iterativo era encerrado.

As vazões requeridas pelos microaspersores localizados na extremidade final do equipamento (lance em balanço) foram elevadas, ultrapassando o limite disponível de bocais apresentado na Tabela 3. Para contornar esse problema, foram empregados dois microaspersores, para aplicar a calda nos locais de maior demanda de vazão, mostrado esquematicamente na Figura 17. Os microaspersores foram instalados nesses locais espaçados em $0,10 \mathrm{~m}$, ficando um a $0,05 \mathrm{~m}$ no sentido ré e o outro a $0,05 \mathrm{~m}$ no sentido vante, em relação ao ponto onde teoricamente seria instalado um único microaspersor.

Com as informações de espaçamento entre microaspersores e vazão obtidos, o passo seguinte foi o dimensionamento hidráulico da linha lateral, com a definição do diâmetro da tubulação de polietileno e dos diâmetros de bocais dos microaspersores a serem efetivamente instalados no protótipo. Os dimensionamentos foram feitos de forma similar à descrita por Maia (1994), no cálculo de linhas laterais para irrigação localizada pelo método trecho-a-trecho. Com auxílio de planilha eletrônica, em cada trecho da tubulação era calculada a perda de carga pela equação (2), somado ou subtraído o desnível e obtida a pressão no microaspersor seguinte. Com esse valor de pressão estimado e a vazão necessária para o microaspersor, era escolhido o diâmetro do bocal que melhor atendesse a essas condições com o menor desvio em relação à vazão necessária. No decorrer do dimensionamento, com as mudanças nas vazões, ocorria a cada passo, mudanças nas perdas de carga e nas pressões do sistema. Através de processo iterativo na planilha eletrônica, os cálculos eram repetidos até se encontrar uma solução onde as variações de vazão e pressão entre iterações era mínima, obtendo-se os resultados finais.

Para evitar o emprego de linhas de polietileno com elevados diâmetros na linha de microaspersores, foram dimensionadas duas linhas: uma 
linha com início (saída da válvula reguladora de pressão) no final do lance em balanço e término na torre móvel do pivô, e outra iniciando na torre móvel e terminando próximo ao ponto do pivô.

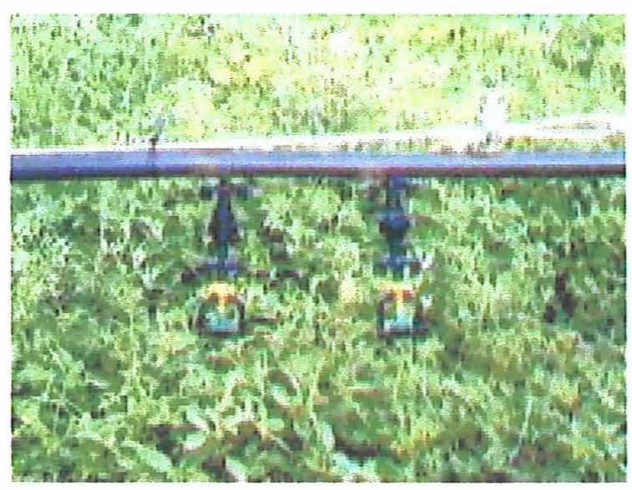

Figura 17 - Ilustração de dois microaspersores operando conjuntamente para a aplicação de calda em uma mesma área de domínio.

\subsubsection{Desenvolvimento do conjunto de acoplamento e regulagem da altura de aplicação}

O conjunto para acoplamento e regulagem da altura de aplicação é composto por cantoneiras metálicas perfuradas, fixadas perpendicularmente na tubulação aérea do pivô central por meio de braçadeiras metálicas especiais, que promovem a sustentação da linha de polietileno com os microaspersores através de cabos de aço e acessórios, conforme apresentado na Figura 18.

As braçadeiras especiais foram confeccionadas em aço chato de 1" de largura por $1 / 8$ "de expessura. A parte superior é acoplada na tubulação de aço do pivô e a parte inferior acopla o tubo de PVC de $50 \mathrm{~mm}$ e as cantoneiras metálicas perfuradas (Figura 19). 


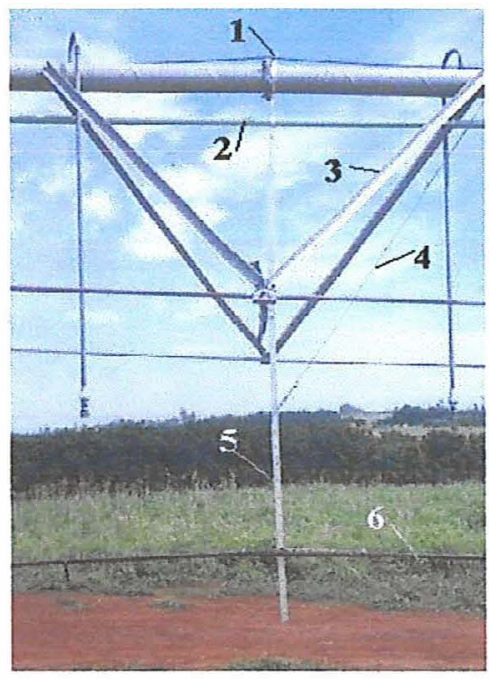

Figura 18 - Visualização de um conjunto para acoplamento e regulagem da altura de aplicação instalado no pivô central: (1) braçadeira metálica; (2) tubo de PVC; (3) diagonal metálica em "V"; (4) cabo de aço; (5) cantoneira metálica perfurada; (6) linha de microaspersores.

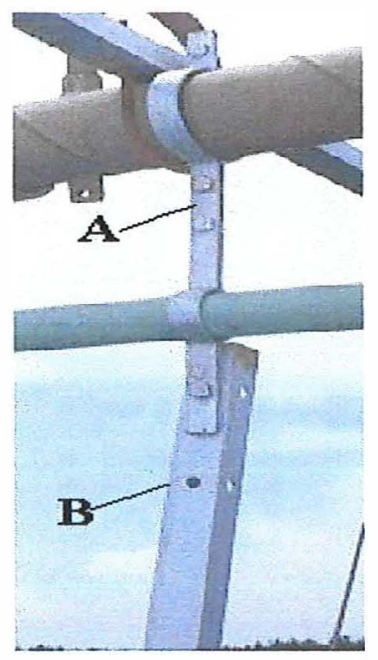

Figura 19 - Ilustração de uma braçadeira metálica de aço chato de 1" (A), dando suporte a uma cantoneira metálica (B).

Foram empregados dois tipos de cantoneiras, denominadas genericamente de cantoneira perfurada e cantoneira lisa, ilustradas na Figura 20. A cantoneira perfurada, é feita em aço galvanizado, com $1,20 \mathrm{~m}$ de comprimento, 
11/4" de largura e 1/8" de espessura, dotada de furos com $7 / 16$ " de diâmetro, espaçados em $0,10 \mathrm{~m}$. Os furos localizados nas pontas da cantoneira foram feitos a $0,05 \mathrm{~m}$ da extremidade. A cantoneira lisa apresenta as mesmas dimensões da cantoneira perfurada, porém com furos somente nas extremidades. A união entre as cantoneiras é feita com parafusos e porcas com rosca de $3 / 8$ " através dos furos. Partindo-se da braçadeira, são instaladas cantoneiras em número suficiente para promover a operação da linha de microaspersores na altura desejada, que é regulada com uma variação de ajuste de $0,10 \mathrm{~m}$, correspondente ao espaçamento entre furos. Nos locais onde não é feita a instalação das linhas de microaspersores, como por exemplo, próximo às braçadeiras, são empregadas as cantoneiras lisas.

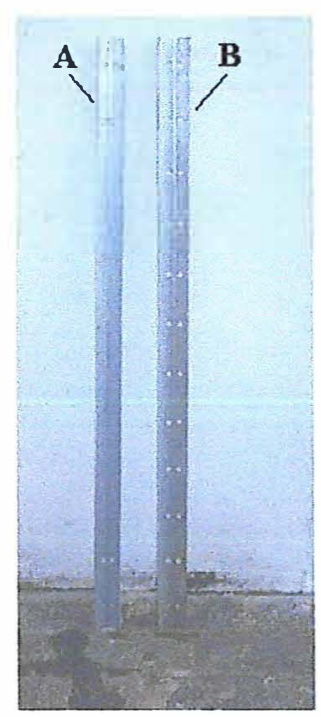

Figura 20 - Ilustração dos modelos de cantoneiras: (A) cantoneira lisa; (B) cantoneira perfurada.

No primeiro vão do pivô central, para aliviar os esforços nas flanges dos tubos de aço e auxiliar na sustentação estrutural do equipamento, são instaladas treliças e diagonais em "V", que fazem parte da composição do pivô (Figura 18). Os conjuntos para acoplamento e regulagem da altura de aplicação 
foram instalados próximos às flanges dos tubos, utilizando-se a estrutura das treliças e diagonais em "V" como forma de apoio às cantoneiras perfuradas, fixando-as na posição perpendicular em relação ao tubo do pivô. Para auxiliar esse apoio, foram instalados cabos de aço de bitola $3 / 16$ " dotados de esticadores, acoplados na tubulação aérea do pivô e nas cantoneiras em posição diagonal (Figura 18).

Para dar suporte aos conjuntos de cantoneiras localizadas no lance em balanço do pivô, onde as treliças e diagonais em "V" são ausentes, foram instaladas cantoneiras lisas de forma cruzada aos tubos de aço, nas quais, com o auxílio de cabos de aço e esticadores, mantém o conjunto de cantoneiras em posição perpendicular aos tubos, conforme ilustrado na Figura 21.

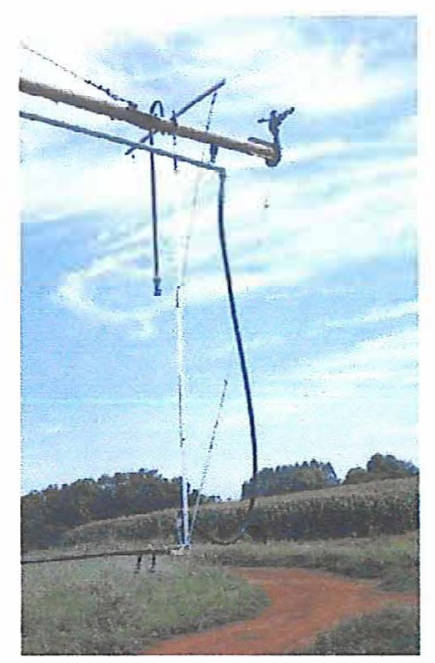

Figura 21 - Ilustração de um conjunto para acoplamento e regulagem da altura de aplicação, instalado no final do lance em balanço do pivô-central.

Foram instalados sete conjuntos de acoplamento e regulagem da altura de aplicação, sendo 5 no vão inicial e 2 no lance em balanço. A Figura 22 ilustra a localização dos conjuntos e a Tabela 5 apresenta o espaçamento entre conjuntos e a distância desses em relação ao ponto do pivô. 


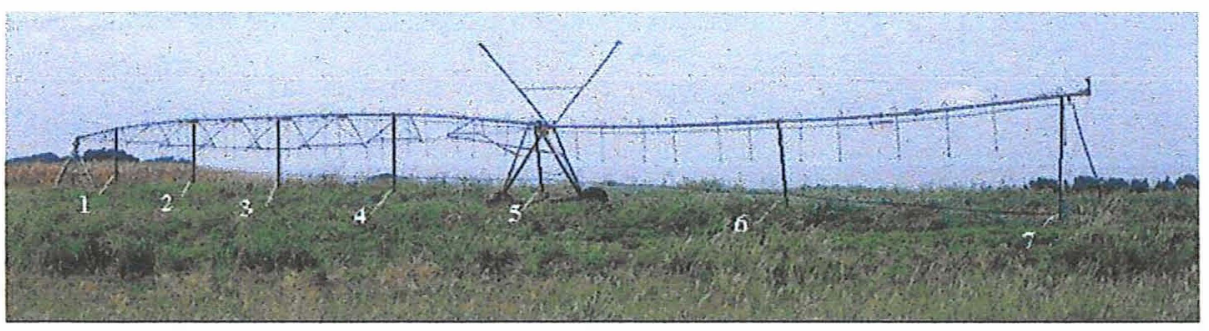

Figura 22 - Localização dos conjuntos para acoplamento e regulagem da altura de aplicação ao longo do equipamento pivô central.

Tabela 5 - Localização ao longo do pivô; distância entre conjuntos e distância ao ponto do pivô dos conjuntos para acoplamento e regulagem da altura de aplicação.

\begin{tabular}{|c|c|c|c|}
\hline $\begin{array}{l}\text { Conjunto de suporte } \\
\text { (Figura 22) }\end{array}$ & $\begin{array}{c}\text { Localização ao longo do } \\
\text { pivô }\end{array}$ & $\begin{array}{c}\text { Distância ao } \\
\text { conjunto } \\
\text { anterior }\end{array}$ & $\begin{array}{c}\text { Distância ao ponto do pivô } \\
\text { (metros) }\end{array}$ \\
\hline 1 & $\begin{array}{l}\text { Flange de união do } 1^{\circ} \text { ao } 2^{\circ} \\
\text { tubo }\end{array}$ & - & 8,00 \\
\hline 2 & $\begin{array}{l}\text { Flange de união do } 3^{\circ} \text { ao } 4^{\circ} \\
\text { tubo }\end{array}$ & 13,52 & 21,52 \\
\hline 3 & $\begin{array}{l}\text { Flange de união do } 5^{\circ} \text { ao } 6^{\circ} \\
\text { tubo }\end{array}$ & 13,4 & 34,92 \\
\hline 4 & $\begin{array}{l}\text { Flange de união do } 7^{\circ} \text { ao } 8^{\circ} \\
\text { tubo }\end{array}$ & 13,22 & 48,14 \\
\hline 5 & Torre móvel & 12,43 & 60,57 \\
\hline 6 & $\begin{array}{l}\text { Início do } 3^{\circ} \text { tubo do lance } \\
\text { em balanço }\end{array}$ & 15,51 & 76,08 \\
\hline 7 & $\begin{array}{l}\text { Último tubo do lance em } \\
\text { balanço, a } 1,10 \mathrm{~m} \\
\text { extremidade final do tubo }\end{array}$ & 12,09 & 88,7 \\
\hline
\end{tabular}

O conjunto de estiramento da linha lateral, ilustrado na Figura 23, é composto por cabos de aço de bitola $3 / 16$ ", nos quais a linha de microaspersores é fixada através de braçadeiras plásticas e por esticadores que promovem o estiramento do cabo de aço e conseqüentemente da linha de microaspersores. Através de um pequeno pedaço de corrente, o cabo de aço e a linha de 
microaspersores são fixados nas cantoneiras por meio de um parafuso e porca com roscas de $1 / 4$ ". A escolha do cabo de bitola $3 / 16$ " é devida a facilidade para a fixação das linhas de polietileno através das braçadeiras plásticas, e pela sua boa resistência a tração.

Nas posições intermediárias entre os conjuntos de suporte foram instalados arames de aço galvanizado, de bitola 1/8", unindo o cabo de aço da linha de microaspersores a uma braçadeira de aço flexível galvanizado (Figura 13), fixada na tubulação aérea do pivô. Esse procedimento auxiliou no suporte da linha lateral, minimizando a catenária da linha quando o protótipo se encontrava em operação.

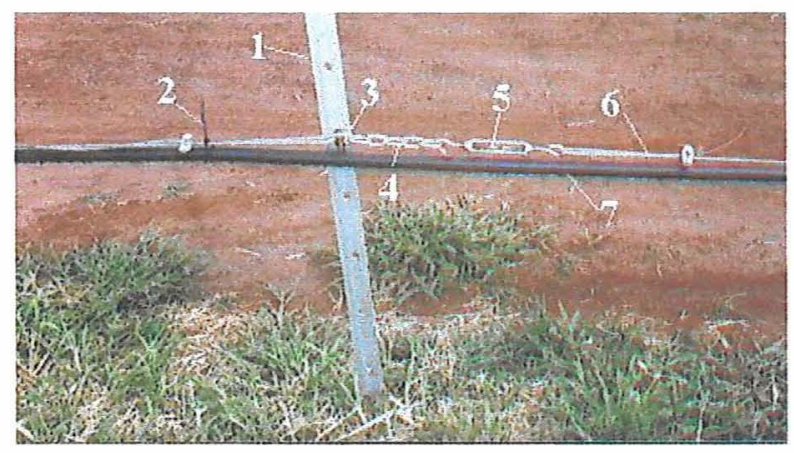

Figura 23 - Ilustração do conjunto de estiramento da linha lateral: (1) cantoneira perfurada; (2) braçadeira plástica; (3) parafuso de fixação de 1/4"; (4) corrente auxiliar para fixação; (5) esticador para cabo de aço; (6) cabo de aço de $3 / 16$ "; linha de polietileno $20 \mathrm{~mm}$ de diâmetro.

O procedimento para a mudança de altura da linha de microaspersores é: (a) soltar os esticadores do cabo de aço da linha (Figura 23); (b) soltar os parafusos de fixação (Figura 22); (c) deslocar a linha para o furo da cantoneira correspondente a altura desejada; (d) prender a linha com os parafusos e estirá-la através dos esticadores. 


\subsection{Avaliações do protótipo a nível de campo}

\subsubsection{Avaliação da unidade de bombeamento e filtragem}

A avaliação da unidade de bombeamento foi feita pela medida das pressões de operação da motobomba; na observação da retenção de impurezas pelo filtro e na medida da vazão de operação do sistema de recirculação contínua.

\subsubsection{Avaliação do cabeçal de controle}

A avaliação do cabeçal de controle consistiu na verificação da retenção de impurezas pelo filtro de discos e na observação do desempenho da válvula de fluxo nas operações de paralisação momentânea de operação da bomba dosadora.

A operação da bomba dosadora foi observada através da avaliação da uniformidade de aplicação de produtos químicos pelo protótipo.

\subsubsection{Avaliação do sistema de adução de calda}

A avaliação do sistema de adução de calda consistiu na observação do funcionamento de seus principais componentes no campo.

\subsubsection{Avaliação do conjunto de controle automatizado da emissão de calda}

Foi observado o desempenho do conjunto na interrupção do fornecimento de água com as paradas da torre móvel. 


\subsubsection{Avaliação do conjunto de emissão de calda}

A avaliação do conjunto de emissão de calda consistiu na observação de seus componentes em operação no campo e na determinação da distribuição de pressão e vazão ao longo da linha de microaspersores. As medidas de pressão foram feitas com um manômetro digital com escala de 0,00$10,00 \mathrm{kgf} / \mathrm{cm}^{2}$ e precisão de $0,01 \mathrm{kgf} / \mathrm{cm}^{2}$, previamente calibrado em um manômetro de peso morto com precisão de $0,1 \%$. As vazões foram determinadas através da coleta do volume de água aplicado por cada microaspersor, através de sacos plásticos reforçados, que posteriormente foram pesados, utilizando-se uma balança de precisão, no Departamento de Engenharia Rural da ESALQ/USP. O valor da tara dos sacos plásticos vazios foram descontados das medidas, obtendose as massas de água coletadas, que correspondem aos volumes coletados e, com os tempos de coleta, foram calculadas as vazões, com três repetições.

Os valores medidos de vazão e pressão ao longo da linha de microaspersores foram comparados aos valores previstos nos procedimentos de dimensionamento. Para verificar a significância da variação entre ambos, foi utilizado o teste de Kolmogorov-Smirnov, aplicado para a análise de duas amostras independentes, apresentado por Campos (1983).

\subsubsection{Avaliação da uniformidade de distribuição de água}

A uniformidade de distribuição de água foi determinada através da coleta da água aplicada pelos microaspersores em uma linha de coletores montada ao longo do raio do pivô central. Os coletores foram instalados com espaçamento eqüidistante de $0,5 \mathrm{~m}$ e com a borda superior a $0,75 \mathrm{~m}$ da superfície do solo. Foram instalados 165 coletores, com diâmetro interno da seção de captação de $0,08 \mathrm{~m}$, 
ficando o primeiro e o último coletor respectivamente a $8,50 \mathrm{~m}$ e $90,50 \mathrm{~m}$ do ponto do pivô, abrangendo toda a área de aplicação de água pelos emissores. A lâmina de água coletada foi calculada pela seguinte expressão:

$$
L c=\operatorname{Vol}(L) / A C
$$

em que $L c$ é a lâmina de água coletada $(\mathrm{mm}) ; \operatorname{Vol}(L)$ é o volume de água coletado (L) e $A C$ é a área de coleta do coletor $\left(5,03 \times 10^{-3} \mathrm{~m}^{2}\right)$. Aplicando-se a equação (6), com o volume de água coletado expresso em $\mathrm{mL}$, tem-se:

$$
L c=0,20 . \operatorname{Vol}(m L)
$$

em que $\operatorname{Vol}(m L)$ é o volume de água coletado em $\mathrm{mL}$.

O conjunto de emissão de calda foi dimensionado para aplicar uma pequena lâmina de água, com valor médio estimado de $0,25 \mathrm{~mm}$. Aplicando-se a equação (7), o volume coletado correspondente a essa lâmina é de $1,25 \mathrm{~mL}$, que é muito pequeno para ser mensurado a nível de campo. Para contornar esse problema adotou-se o procedimento de passar o pivô central diversas vezes sobre a linha de coletores, até que um volume mensurável de água fosse acumulado. A lâmina aplicada pelo protótipo era então obtida dividindo-se a lâmina total coletada pelo número de passagens do equipamento sobre a linha. Para evitar problemas de deriva e desuniformidade de aplicação causados pelo vento, como também problemas de evaporação de água, o ensaio foi realizado no período noturno. Com o objetivo de minimizar o poder evaporante do ar e o fluxo de calor do solo para a atmosfera durante o ensaio, a área foi irrigada algumas horas antes do mesmo, ao final do dia. Antes do início do ensaio os filtros do sistema foram devidamente limpos.

Com os valores de lâmina de água coletada calculou-se a lâmina média aplicada pela seguinte expressão:

$$
L m=\sum_{i=1}^{n}(L c i . R i) / \sum_{i=1}^{n} R i
$$


em que $L m$ é a lâmina média aplicada ( $\mathrm{mm})$; $L c i$ é a lâmina de água coletada no iésimo coletor (mm) e $R i$ é a distância do i-ésimo coletor ao ponto do pivô (m).

A uniformidade das lâminas de água aplicadas foi quantificada através do Coeficiente de Uniformidade de Christiansen, que utiliza o desvio médio absoluto como medida de dispersão (Frizzone, 1992):

$$
C U C=100 .\left[1-\left(\sum_{i=1}^{n}|L c i-L m|\right) /(N . L m)\right]
$$

em que $C U C$ é o Coeficiente de Uniformidade de Christiansen (\%) e $N$ é o número total de coletores.

\subsubsection{Avaliação da uniformidade de aplicação de produtos químicos pelo protótipo}

Com o objetivo de verificar a distribuição de produtos químicos aplicados pelo protótipo foi realizado um ensaio onde uma solução concentrada de cloreto de potássio $(\mathrm{KCl})$ foi injetada no sistema através da bomba dosadora do cabeçal de controle. Antes do início do ensaio, uma amostra de água foi coletada ("prova em branco"). Minutos depois do início da injeção (15 minutos) foram coletadas amostras da solução aplicada pelos microaspersores, diretamente na saída dos mesmos, através de recipientes plásticos especiais, como também da solução concentrada injetada, através do amostrador da bomba dosadora para essa finalidade (Figura 9). Após as coletas, as amostras foram enviadas para análise em laboratório especializado ${ }^{8}$, onde os teores de íon potássio nas amostras foram determinados. Os teores de potássio obtidos nas amostras foram comparados com o teor previsto através das seguintes equações:

$$
C_{f}=\left[\left(Q_{f}-Q i\right) . C_{l}+(Q i . C i)\right] / Q_{f}
$$

\footnotetext{
${ }^{8}$ Unithal Laboratório Agroquímico, Campinas, SP.
} 
em que $C f$ é a concentração final da solução aplicada após a injeção (ppm); $Q f$ é a vazão do sistema que passa pelo cabeçal de controle (L/h); $Q i$ é a vazão de solução concentrada injetada $(\mathrm{L} / \mathrm{h}) ; C_{l}$ é a concentração do íon potássio na água, em ppm ("solução em branco"); $C i$ é a concentração de íon potássio na solução concentrada (ppm). 


\section{RESULTADOS E DISCUSSÃO}

\subsection{Avaliação da unidade de bombeamento e filtragem}

A vazão medida no sistema de recirculação contínua foi de $2,12 \mathrm{~m}^{3} / \mathrm{h}$, muito próximo ao valor de $2,23 \mathrm{~m}^{3} / \mathrm{h}$ apresentado pelo fabricante para a associação bocal-regulador. Operando-se a motobomba com o sistema de recirculação contínua durante várias horas, não foi observado aquecimento na bomba, mostrando que o sistema operou de maneira eficiente.

As pressões de operação da motobomba medidas foram: 46,6mca, operando com vazão nula; 44,1mca, operando somente com o sistema de recirculação contínua (vazão de $2,12 \mathrm{~m}^{3} / \mathrm{h}$ ); $43,8 \mathrm{mca}$, operando com o sistema de recirculação contínua e o protótipo em operação (vazão total de $5,58 \mathrm{~m}^{3} / \mathrm{h}$ ). Esses valores estão muito próximos aos apresentados na curva característica da motobomba (Figura 5).

O filtro de discos reteve os sedimentos e algas contidas na água de maneira eficiente, sem a necessidade de constantes limpezas do elemento filtrante durante os períodos de funcionamento do protótipo. 


\subsection{Avaliação do cabeçal de controle}

O filtro de discos do cabeçal de controle operou satisfatoriamente, impedindo a obstrução dos emissores por sedimentos e algas contidas na água. A válvula de fluxo KSB Hydroflow foi eficiente na paralisação do funcionamento da bomba dosadora, seja com a interrupção do fornecimento de água (fechamento do registro), ou durante as paradas da torre móvel.

\subsection{Avaliação do sistema de adução de calda}

Todos os componentes do sistema de adução de calda operaram de forma satisfatória, com as tubulações de PVC mantendo-se rigidamente acopladas à tubulação aérea do pivô central durante a operação do sistema.

\subsection{Avaliação do conjunto de controle automatizado da emissão de calda}

O conjunto de controle automatizado da emissão de calda funcionou perfeitamente, com as válvulas solenóides promovendo a liberação/interrupção do fornecimento de calda com o caminhamento/parada da torre móvel, de maneira visualmente instantânea. A Figura 24 mostra a torre móvel no momento de sua parada e em caminhamento, com a liberação de água aos emissores.

\subsection{Avaliação do conjunto de emissão de calda}

Todos os componentes do conjunto de emissão de calda operaram de forma satisfatória, com as válvulas antigota L.P.D. promovendo a imediata 
interrupção do fluxo de água aos microaspersores durante as paradas da torre móvel, com a conseqüente interrupção do fornecimento de calda pelo fechamento das válvulas solenóides. A Figura 25 apresenta, em funcionamento, o conjunto de emissão de calda instalado no primeiro vão do pivô central.

(A)

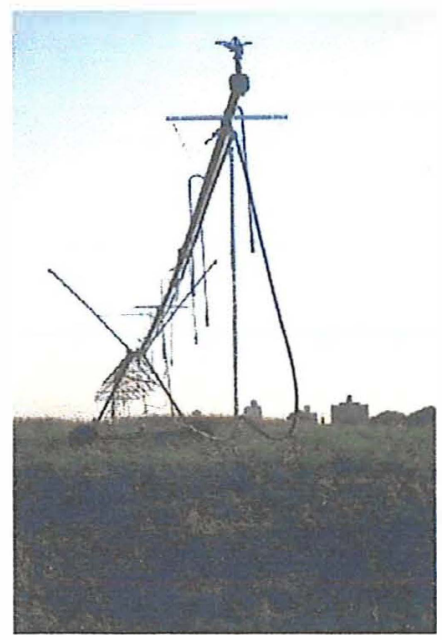

(B)

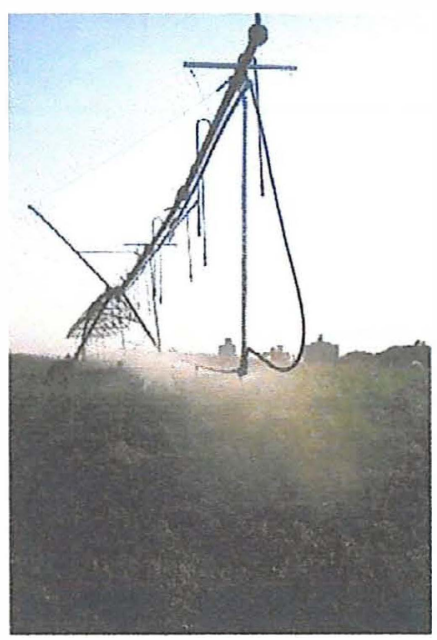

Figura 24 - Ilustração do protótipo durante o período de parada da torre móvel (A) e durante o caminhamento da torre (B).

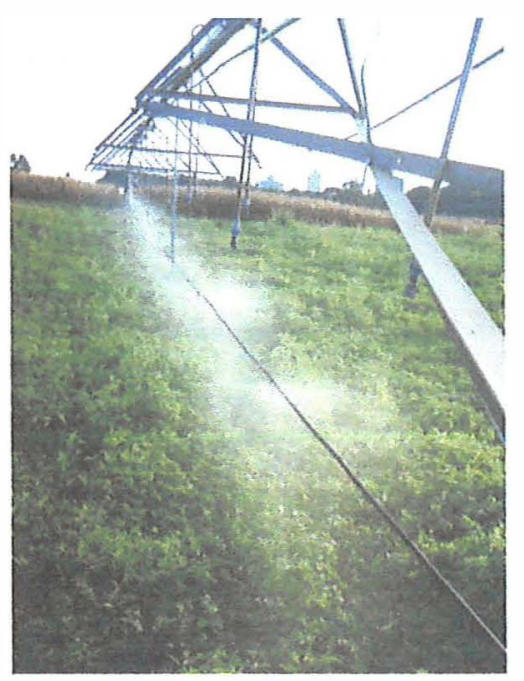

Figura 25 - Conjunto de emissão de calda em funcionamento, instalado no primeiro vão do pivô central. 
Através das metodologias de cálculo apresentadas no ítem 3.3.6, foram dimensionados os conjuntos de emissão de calda do primeiro vão do equipamento e do lance em balanço, apresentados nas Tabelas 6 e 7. Nos dimensionamentos foi computada a perda de carga localizada na inserção dos microaspersores, somando-se $0,11 \mathrm{~m}$ de comprimento equivalente de tubulação por microaspersor inserido nos respectivos trechos, conforme determinação de Botrel (1984), e dessa forma, nos trechos com dois microaspersores operando conjuntamente (Figura 17), somou-se o valor de 0,22m ao comprimento desses trechos (colunas CP hf., Tabelas 6 e 7). A pressão de entrada na linha (saída da válvula reguladora de pressão) utilizada nos cálculos foi de $22,5 \mathrm{mca}$, com base no ensaio da válvula apresentado no item 3.3.6.3. Os trechos de número "l" nas Tabelas 6 e 7 referem-se àqueles localizados entre a saída da válvula reguladora de pressão aos primeiros microaspersores da linha. A lâmina de água empregada nos cálculos foi de $0,267 \mathrm{~mm} / \mathrm{h}$, que foi o menor valor que possibilitou o emprego dos bocais comerciais do microaspersor, com pequenos desvios entre a vazão necessária e a vazão prevista pela equação (1). Como as diferenças de nível entre os trechos, no sentido de fluxo da água, foram sempre em aclive, esses valores foram subtraídos nos cálculos das pressões de operação dos microaspersores.

O tempo mínimo para o pivô central dar uma volta completa, ou seja, com o relê percentímetro regulado em $100 \%$, foi determinado em condições de campo e obteve-se o valor de 133 minutos e 48 segundos (2,23 horas). Nessa regulagem, a torre móvel caminha 59 segundos e para durante 1 segundo. Como o pivô levou 133 minutos e 48 segundos para dar uma volta, ele permaneceu, em valor aproximado, 133,48 segundos parado ao longo da volta, ou seja, a torre móvel do pivô permaneceu em deslocamento 131 minutos e 35 segundos $(2,19$ horas). Como o protótipo somente aplica a calda quando ocorre o deslocamento da torre, o tempo de operação do pivô (To, equação 5), considerado nos dimensionamentos foi de $2,19 \mathrm{~h}$. 
O aumento da variação de vazão dos microaspersores (coluna VAR. VAZÃO, \%, Tabela 6) nos trechos finais do conjunto de emissão de calda do primeiro vão é devido ao diâmetro do bocal de $0,8 \mathrm{~mm}$, que é o mínimo disponível comercialmente, não havendo portanto, a possibilidade de fornecer menores vazões.

Tabela 6 - Dimensionamento do conjunto de emissão de calda do primeiro vão: Número do recho (TR.); distância ao ponto do pivô (DIST., m); comprimento do trecho (CP., $\mathrm{m}$ ); comprimento do recho empregado no cálculo da perda de carga (CP hf., $\mathrm{m}$ ); diâmetro dos bocais (D.B, $\mathrm{mm}$ ); número de emissores no final do trecho (N.E, $\mathrm{m}$ ); vazão necessária, (VAZÃO NEC., L/h); vazão estimada a ser aplicada pelo microaspersor (VAZÃO APL., L/h); variação percentual entre a vazão estimada a ser aplicada pelo microaspersor e a vazão necessária (VAR. VAZÃO, \%); diferença de nível no recho (aclive), (D.N, m); vazão do trecho (VAZÃO ACUM., L/h); diâmetro interno da tubulação de polietileno no trecho $(\mathrm{D}, \mathrm{mm})$; perda de carga no trecho (Hf, mca); pressão de operação do microaspersor (PF, mca).

\begin{tabular}{|c|c|c|c|c|c|c|c|c|c|c|c|c|c|}
\hline TR. & $\begin{array}{c}\text { DIST. } \\
\text { (m) }\end{array}$ & $\begin{array}{l}\text { CP. } \\
\text { (m) }\end{array}$ & $\begin{array}{c}\mathrm{CP} \text { hf. } \\
\text { (m) }\end{array}$ & $\begin{array}{c}\text { D.B } \\
\text { (mm) }\end{array}$ & N.E & $\begin{array}{c}\text { VAZÃO } \\
\text { NEC. } \\
(\mathbf{L} / \mathbf{h})\end{array}$ & $\begin{array}{c}\text { VAZAO } \\
\text { APL. } \\
(\mathbf{L} / \mathbf{h})\end{array}$ & $\begin{array}{c}\text { VAR. } \\
\text { VAZÄO } \\
(\%)\end{array}$ & $\begin{array}{l}\text { D.N } \\
\text { (m) }\end{array}$ & $\begin{array}{c}\text { VAZÃO } \\
\text { ACUM. } \\
(\mathbf{L} / \mathbf{h})\end{array}$ & $\underset{(\mathbf{m m})}{D}$ & $\underset{\text { (mca) }}{\text { Hf }}$ & $\underset{\text { (mca) }}{\text { PF }}$ \\
\hline 1 & 60,6 & 0,75 & 0,75 & - & 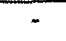 & - & - & - & 0,01 & 1517,1 & 20 & 0,085 & 22,4 \\
\hline 2 & 59,8 & 4,00 & 4,22 & 1,4 & 2 & 183,2 & 189,3 & 3,32 & 0,04 & 1517,1 & 20 & 0,480 & 21,9 \\
\hline 3 & 55,8 & 4,00 & 4,22 & 1,3 & 2 & 171,0 & 168,6 & $-1,40$ & 0,04 & 1327,8 & 20 & 0,380 & 21,5 \\
\hline 4 & 51,8 & 4,00 & 4,22 & 1,3 & 2 & 158,7 & 167,2 & 5,37 & 0,04 & 1159,2 & 20 & 0,300 & 21,1 \\
\hline 5 & 47,8 & 4,00 & 4,22 & 1,2 & 2 & 146,5 & 148,9 & 1,65 & 0,06 & 992,0 & 20 & 0,228 & 20,8 \\
\hline 6 & 43,8 & 4,00 & 4,11 & 1,8 & 1 & 134,2 & 130,6 & $-2,68$ & 0,06 & 843,1 & 20 & 0,167 & 20,6 \\
\hline 7 & 39,8 & 4,00 & 4,11 & 1,8 & 1 & 122,0 & 130,0 & 6,61 & 0,06 & 712,5 & 20 & 0,124 & 20,4 \\
\hline 8 & 35,8 & 4,00 & 4,11 & 1,6 & 1 & 96,0 & 108,8 & 13,39 & 0,28 & 582,4 & 20 & 0,087 & 20,0 \\
\hline 9 & 32,3 & 3,50 & 3,61 & 1,3 & 1 & 86,6 & 80,8 & $-6,65$ & 0,25 & 473,6 & 20 & 0,054 & 19,7 \\
\hline 10 & 28,8 & 3,50 & 3,61 & 1,3 & 1 & 66,2 & 80,3 & 21,25 & 0,25 & 392,8 & 20 & 0,039 & 19,4 \\
\hline 11 & 25,8 & 3,00 & 3,11 & 1,1 & 1 & 59,3 & 53,4 & $-10,02$ & 0,22 & 312,5 & 20 & 0,022 & 19,2 \\
\hline 12 & 22,8 & 3,00 & 3,11 & 1,0 & 1 & 43,7 & 48,6 & 11,26 & 0,07 & 259,2 & 20 & 0,016 & 19,1 \\
\hline 13 & 20,3 & 2,50 & 2,61 & 0,8 & 1 & 38,9 & 35,2 & $-9,37$ & 0,06 & 210,6 & 20 & 0,009 & 19,1 \\
\hline 14 & 17,8 & 2,50 & 2,61 & 0,8 & 1 & 27,3 & 35,2 & 28,96 & 0,06 & 175,3 & 20 & 0,007 & 19,0 \\
\hline 15 & 15,8 & 2,00 & 2,11 & 0,8 & 1 & 24,2 & 35,1 & 45,07 & 0,05 & 140,2 & 20 & 0,004 & 18,9 \\
\hline 16 & 13,8 & 2,00 & 2,11 & 0,8 & 1 & 21,1 & 35,1 & 65,86 & 0,05 & 105,1 & 20 & 0,002 & 18,9 \\
\hline 17 & 11,8 & 2,00 & 2,11 & 0,8 & 1 & 18,1 & 35,0 & 93,71 & 0,05 & 70,0 & 20 & 0,001 & 18,8 \\
\hline 18 & 9,8 & 2,00 & 2,11 & 0,8 & 1 & 15,0 & 35,0 & 132,93 & 0,05 & 35,0 & 26 & 0,000 & 18,8 \\
\hline
\end{tabular}


Tabela 7 - Dimensionamento do conjunto de emissão de calda do lance em balanço: Número do trecho (TR.); distância ao ponto do pivô (DIST., m); comprimento do trecho (CP., m); comprimento do trecho empregado no cálculo da perda de carga (CP hf., m); diâmetro dos bocais (D.B, mm); número de emissores no final do trecho (N.E, m); vazão necessária, (VAZÃO NEC., L/h); vazão estimada a ser aplicada pelo microaspersor (VAZÃO APL., L/h); variação percentual entre a vazão estimada a ser aplicada pelo microaspersor e a vazão necessária (VAR. VAZÃO, \%); diferença de nível no trecho (aclive), (D.N, m); vazão do trecho (VAZÃO ACUM., L/h); diâmetro interno da tubulação de polietileno no trecho (D, $\mathrm{mm})$; perda de carga no trecho (Hf, mca); pressão de operação do microaspersor (PF, mca).

\begin{tabular}{|c|c|c|c|c|c|c|c|c|c|c|c|c|c|}
\hline TR. & $\begin{array}{c}\text { DIST. } \\
\text { (m) }\end{array}$ & $\begin{array}{l}\text { CP. } \\
\text { (m) }\end{array}$ & $\begin{array}{c}\text { CP hf. } \\
\text { (m) }\end{array}$ & $\begin{array}{l}\text { D.B } \\
(\mathbf{m} \mathrm{m})\end{array}$ & N.E & $\begin{array}{c}\text { VAZÃo } \\
\text { NEC. } \\
\text { (L/h) }\end{array}$ & $\begin{array}{l}\text { VAZÃo } \\
\text { APL. } \\
\text { (L/h) }\end{array}$ & $\begin{array}{c}\text { VAR. } \\
\text { VAZÃO } \\
\text { (\%) }\end{array}$ & $\begin{array}{l}\text { D.N } \\
\text { (m) }\end{array}$ & $\begin{array}{c}\text { VAZÃO } \\
\text { ACUM. } \\
\text { (L/h) }\end{array}$ & $\underset{(\mathrm{mm})}{D}$ & $\underset{(\mathrm{mca})}{\mathbf{H f}}$ & $\underset{\text { (mca) }}{\mathbf{P F}}$ \\
\hline 1 & 88,1 & 0,3 & 0,3 & $=$ & - & - & - & - & - & 1712,2 & 20 & 0,042 & 22,5 \\
\hline 2 & 87,8 & 4 & 4,22 & 1,8 & 2 & 269,0 & 268,8 & $-0,07$ & 0,04 & 1712,2 & 20 & 0,593 & 21,8 \\
\hline 3 & 83,8 & 4 & 4,22 & 1,8 & 2 & 256,8 & 265,1 & 3,23 & 0,17 & 1443,3 & 20 & 0,440 & 21,2 \\
\hline 4 & 79,8 & 4 & 4,22 & 1,8 & 2 & 244,5 & 262,8 & 7,48 & 0,05 & 1178,2 & 20 & 0,308 & 20,9 \\
\hline 5 & 75,8 & 4 & 4,22 & 1,8 & 2 & 232,3 & 261,2 & 12,47 & 0,05 & 915,4 & 20 & 0,198 & 20,6 \\
\hline 6 & 71,8 & 4 & 4,22 & 1,6 & 2 & 220,0 & 219,9 & $-0,05$ & 0,05 & 654,2 & 20 & 0,110 & 20,4 \\
\hline 7 & 67,8 & 4 & 4,22 & 1,6 & 2 & 207,7 & 218,0 & 4,93 & 0,28 & 434,3 & 20 & 0,054 & 20,1 \\
\hline 8 & 63,8 & 4 & 4,22 & 1,6 & 2 & 195,5 & 216,3 & 10,64 & 0,28 & 216,3 & 20 & 0,016 & 19,8 \\
\hline
\end{tabular}

As Tabelas 8 e 9 apresentam valores de pressão medida (mca) e pressão estimada (mca) em alguns trechos dos conjuntos de emissão de calda do primeiro vão e do lance em balanço. Observa-se que os valores medidos foram muito próximos aos valores estimados. Aplicando-se o teste de KolmogorovSmirnov, para a análise de duas amostras independentes, verificou-se que a diferença entre esses valores não foi significativa (estatística " $D$ " igual a 0,4 , correspondente a um nível de significância de 0,819 , para o conjunto de emissão de calda do primeiro vão; estatística " $D$ " igual a 0,2 , correspondente a um nível de significância de 0,999 , para o conjunto de emissão de calda do lance em balanço). 
Tabela 8 - Local de medida da pressão; pressão medida (mca) e pressão estimada (mca) referentes ao conjunto de emissão de calda do primeiro vão.

\begin{tabular}{|c|c|c|}
\hline $\begin{array}{c}\text { LOCAL DE MEDIDA DA } \\
\text { PRESSÃO }\end{array}$ & $\begin{array}{c}\text { PRESSÃO MEDIDA } \\
\text { (mca) }\end{array}$ & $\begin{array}{c}\text { PRESSÃO ESTIMADA } \\
\text { (mca) }\end{array}$ \\
\hline Saída do regulador & 22,5 & 22,5 \\
\hline Final do Trecho 3 & 21,1 & 21,5 \\
\hline Final do Trecho 6 & 20,4 & 20,6 \\
\hline Final do Trecho 9 & 19,1 & 19,7 \\
\hline Final do Trecho 16 & 18,8 & 18,9 \\
\hline
\end{tabular}

Tabela 9 - Local de medida da pressão; pressão medida (mca) e pressão estimada (mca) referentes ao conjunto de emissão de calda do lance em balanço.

\begin{tabular}{|c|c|c|}
\hline $\begin{array}{c}\text { LOCAL DE MEDIDA DA } \\
\text { PRESSÃO }\end{array}$ & $\begin{array}{c}\text { PRESSÃO MEDIDA } \\
\text { (mca) }\end{array}$ & $\begin{array}{c}\text { PRESSÃO ESTIMADA } \\
\text { (mca) }\end{array}$ \\
\hline Saída do regulador & 22,4 & 22,5 \\
\hline Final do Trecho 2 & 21,7 & 21,8 \\
\hline Final do Trecho 3 & 21,3 & 21,2 \\
\hline Final do Trecho 5 & 20,9 & 20,6 \\
\hline Final do Trecho 8 & 19,3 & 19,8 \\
\hline
\end{tabular}

A Tabela 10 apresenta as vazões medidas e as vazões estimadas dos microaspersores. A Figura 26 mostra o diagrama de dispersão desses valores. Observa-se pela Tabela 10 que as vazões medidas e as vazões estimadas seguiram a mesma tendência de elevação, conforme aumenta-se a distância de localização do microaspersor ao ponto do pivô. Na Figura 26 observa-se que as vazões medidas e as vazões estimadas apresentaram valores similares, com as vazões medidas, de maneira geral, com maiores valores em relação às vazões estimadas. A vazão total de operação do protótipo, obtida somando-se os valores medidos em cada microaspersor, foi de $3445,26 \mathrm{~L} / \mathrm{h}$, sendo $7,02 \%$ maior do que a vazão total estimada de $3229,44 \mathrm{~L} / \mathrm{h}$. As variações entre os valores medidos e os valores 
estimados podem ser devidas a imprecisões nas medidas de vazão ou ao coeficiente de variação de vazão dos emissores. O teste de Kolmogorov-Smirnov indicou que a diferença entre esses valores não foi significativa (valor da estatística " $D$ " igual a 0,25 , correspondendo a um nível de significância de $0,441)$.

Tabela 10 - Distância do microaspersor em relação ao ponto do pivô (DIST.); Vazão estimada (L/h); Vazão medida (L/h) e Variação percentual $(\%)$ entre a Vazão medida $(L / h)$ em relação a Vazão estimada $(L / h)$.

\begin{tabular}{|c|c|c|c|c|c|c|c|}
\hline $\begin{array}{c}\text { DIST. } \\
(\mathbf{m})\end{array}$ & $\begin{array}{c}\text { Vazão } \\
\text { estimada } \\
(\mathbf{L} / \mathbf{h})\end{array}$ & $\begin{array}{c}\text { Vazão } \\
\text { medida } \\
\mathbf{( L / h})\end{array}$ & $\begin{array}{c}\text { Variação } \\
\text { Percentual } \\
(\mathbf{\%})\end{array}$ & $\begin{array}{c}\text { DIST. } \\
(\mathbf{m})\end{array}$ & $\begin{array}{c}\text { Vazão } \\
\text { estimada } \\
(\mathbf{L} / \mathbf{h})\end{array}$ & $\begin{array}{c}\text { Vazão } \\
\text { medida } \\
(\mathbf{L} / \mathbf{h})\end{array}$ & $\begin{array}{c}\text { Variação } \\
\text { Percentual } \\
(\mathbf{\%})\end{array}$ \\
\hline 9,8 & 34,98 & 46,48 & 32,87 & 51,8 & 167,24 & 178,6 & 6,79 \\
\hline 11,8 & 35,03 & 40,68 & 16,14 & 55,8 & 168,59 & 177,28 & 5,15 \\
\hline 13,8 & 35,07 & 36,6 & 4,35 & 59,8 & 189,31 & 200,63 & 5,98 \\
\hline 15,8 & 35,12 & 44,5 & 26,68 & 63,8 & 216,3 & 213,95 & $-1,09$ \\
\hline 17,8 & 35,18 & 42,8 & 21,69 & 67,8 & 218 & 225,41 & 3,4 \\
\hline 20,3 & 35,24 & 39,13 & 11,04 & 71,8 & 219,9 & 235,78 & 7,22 \\
\hline 22,8 & 48,59 & 53,62 & 10,35 & 75,8 & 261,23 & 253,61 & $-2,92$ \\
\hline 25,8 & 53,36 & 51,71 & $-3,1$ & 79,8 & 262,81 & 293,05 & 11,51 \\
\hline 28,8 & 80,27 & 88,91 & 10,77 & 83,8 & 265,07 & 297,44 & 12,21 \\
\hline 32,3 & 80,86 & 83,44 & 3,19 & 87,8 & 268,85 & 285,12 & 6,05 \\
\hline 35,8 & 108,86 & 107,41 & $-1,33$ & Total & 3229,44 & 3456,26 & 7,02 \\
\hline 39,8 & 130,04 & 143,95 & 10,7 & Máximo & 268,85 & 297,44 & 32,87 \\
\hline 43,8 & 130,63 & 151,22 & 15,76 & Minimo & 34,98 & 36,60 & $-3,10$ \\
\hline 47,8 & 148,91 & 164,96 & 10,78 & & & & \\
\hline
\end{tabular}

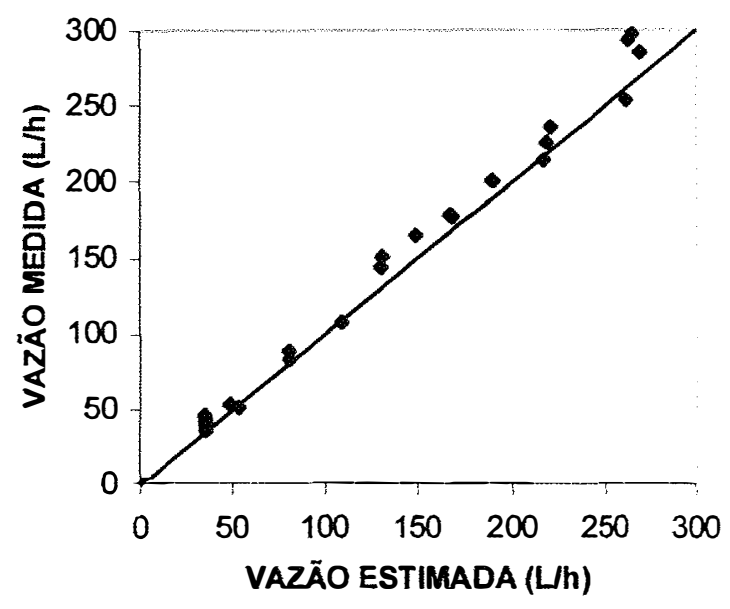

Figura 26. Diagrama de dispersão entre a Vazão medida (L/h) e a Vazão estimada $(\mathrm{L} / \mathrm{h})$ dos microaspersores. 


\subsection{Resultados do ensaio de uniformidade de distribuição de água}

No ensaio de uniformidade de distribuição de água, o pivô central foi passado quinze vezes sobre a linha de coletores, operando-se o equipamento caminhando no sentido de "avanço" e no sentido de "reversão". A lâmina total aplicada em cada coletor foi dividida pelo número de passagens e dessa forma obtiveram-se os valores médios aplicados, apresentados na Tabela 11. A Figura 27 mostra o perfil das lâminas de água aplicadas ao longo do equipamento. Observa-se que próximo ao ponto do pivô ocorrem maiores valores de lâminas, devido a maior vazão fornecida pelos microaspersores, e que, os últimos emissores tiveram um raio de alcance útil de $1,0 \mathrm{~m}$. Assim, definiu-se uma faixa útil de aplicação (Figura 27), dentro da qual as lâminas de água apresentam valores com tendência de distribuição uniforme, iniciando-se a $14,50 \mathrm{~m}$ do ponto do pivô (coletor 13) e terminando a $89,00 \mathrm{~m}$ do ponto do pivô (coletor 162). Nessa faixa, a lâmina média de água coletada foi de $0,243 \mathrm{~mm}$, com um Coeficiente de Uniformidade de Christiansen igual a $82 \%$, valor considerado indicativo de uma boa uniformidade de distribuição. Nos coletores localizados próximos aos microaspersores observam-se maiores valores de lâminas de água, devido a respingos causados pelo impacto dos jatos de água no corpo dos microaspersores, que contribuíram para diminuir o valor do Coeficiente de Uniformidade de Christiansen, podendo causar problemas de fitotoxidade nas culturas com a aplicação de determinados produtos químicos, o que necessita ser melhor estudado.

A área de aplicação de água, compreendida entre o coletor 13 (localizado a $14,50 \mathrm{~m}$ do ponto do pivô) e o coletor 162 (localizado a $89,00 \mathrm{~m}$ do ponto do pivô) é de 2,45 hectares. Considerando-se a lâmina média de água coletada de $0,243 \mathrm{~mm}$, pode-se estimar que o protótipo aplicou um volume de 2430 litros de água por hectare nessa faixa. Baseando-se nos volumes de calda 
Tabela 11 - Número do coletor; distância ao ponto do pivô $(\mathrm{m})$ e lâmina média de água coletada $(\mathrm{mm})$, referentes ao ensaio de distribuição de água.

\begin{tabular}{|c|c|c|c|c|c|c|c|c|c|c|c|}
\hline $\begin{array}{l}\text { Número } \\
\text { do } \\
\text { coletor }\end{array}$ & \begin{tabular}{|c|} 
Distância \\
ao ponto \\
do pivô \\
(m)
\end{tabular} & $\begin{array}{c}\text { Lâmina } \\
\text { média } \\
\text { coletada } \\
\text { (mm) } \\
\end{array}$ & $\begin{array}{l}\text { Número } \\
\text { do } \\
\text { coletor }\end{array}$ & \begin{tabular}{|c|}
$\begin{array}{c}\text { Distância } \\
\text { ao ponto } \\
\text { do piv6 } \\
\text { (m) }\end{array}$ \\
\end{tabular} & 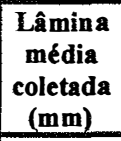 & $\begin{array}{c}\text { Número } \\
\text { do } \\
\text { coletor }\end{array}$ & \begin{tabular}{|c|} 
Distância \\
20 ponto \\
do pivô \\
(m)
\end{tabular} & $\begin{array}{c}\text { Lâmina } \\
\text { média } \\
\text { coletada } \\
\text { (mm) } \\
\end{array}$ & $\begin{array}{c}\text { Número } \\
\text { do } \\
\text { coletor }\end{array}$ & $\begin{array}{c}\text { Distância } \\
\text { ao ponto } \\
\text { do pivô } \\
\text { (m) }\end{array}$ & \begin{tabular}{|c}
$\begin{array}{c}\text { Lâmina } \\
\text { média } \\
\text { coletada } \\
(\mathrm{mm})\end{array}$ \\
\end{tabular} \\
\hline 1 & 8,50 & 0,11 & 43 & 29,50 & 0,23 & 85 & 50,50 & 0,20 & 127 & 71,50 & 0,27 \\
\hline 2 & 9,00 & 0,19 & 44 & 30,00 & 0,24 & 86 & 51,00 & 0,21 & 128 & 72,00 & $\mathbf{0 , 3 3}$ \\
\hline 3 & 9,50 & 0,43 & 45 & 30,50 & 0,23 & 87 & 51,50 & 0,36 & 129 & 72,50 & 0,23 \\
\hline 4 & 10,00 & 0,56 & 46 & 31,00 & 0,21 & 88 & 52,00 & 0,37 & 130 & 73,00 & 0,23 \\
\hline 5 & 10,50 & 59 & 47 & 31,50 & 0,20 & 89 & 52,50 & 0,23 & 131 & 73,50 & 0,23 \\
\hline 6 & 11,00 & 51 & 48 & 32,00 & 0,24 & 90 & 53,00 & 0,23 & 132 & 74,00 & 0,21 \\
\hline 7 & 11,50 & 0,67 & 49 & 32,50 & 0,25 & 91 & 53,50 & 0,20 & 133 & 74,50 & 0,20 \\
\hline 8 & 12,00 & 0,63 & 50 & 33,00 & 0,21 & 92 & 54,00 & 0,19 & 134 & 75,00 & 0,19 \\
\hline 9 & 12,50 & & 51 & 33,50 & 0,20 & 93 & 54,50 & 0,19 & 135 & 75,50 &, 24 \\
\hline 10 & 13,00 & 36 & 52 & 34,00 & 0,19 & 94 & 55,00 & 20 & 136 & 76,00 &, 36 \\
\hline 11 & 13,50 & 0,51 & 53 & 34,50 & 0,19 & 95 & 55,50 & 0,33 & 137 & 76,50 & 0,27 \\
\hline 12 & 14,00 & 0,45 & 54 & 35,00 & 0,21 & 96 & 56,00 & $\mathbf{0 , 3 7}$ & 138 & 77,00 & 0,28 \\
\hline 13 & 14,50 & 0,28 & 55 & 35,50 & 0,32 & 97 & 56,50 & 0,23 & 139 & 77,50 & 0,27 \\
\hline 14 & 0 & 28 & 56 & 10 & 0 & 98 & 57,00 & 24 & 140 & 78,00 &, 24 \\
\hline 15 & 50 & & 57 & 50 & 0,24 & 99 & 57,50 & 20 & 141 & 78,50 &, 23 \\
\hline 16 & 16,00 & 0,51 & 58 & 37,00 & 0,27 & 100 & 58,00 & 0,19 & 142 & 79,00 & 0,24 \\
\hline 17 & 16,50 & 0,28 & 59 & 37,50 & 0,24 & 101 & 58,50 & 0,19 & 143 & 79,50 & 0,33 \\
\hline 18 & 17,00 & 0,25 & 60 & 38,00 & 0,24 & 102 & 59,00 & 0,20 & 144 & 80,00 & $\mathbf{0 , 3 3}$ \\
\hline 19 & 50 & & 61 & 38,50 & 0,24 & 103 & 59,50 & 0,33 & 145 & 80,50 & 0,33 \\
\hline 20 & 18,00 & 0,37 & 62 & 39,00 & 0,23 & 104 & 60,00 & 0,40 & 146 & 81,00 & 0,24 \\
\hline 21 & 18,50 & 0,24 & 63 & 39,50 & 0,24 & 105 & 60,50 & 0,27 & 147 & 81,50 & 0,24 \\
\hline 22 & 19,00 & 0,24 & 64 & 40,00 & 0,24 & 106 & 61,00 & 0,23 & 148 & 82,00 & 0,24 \\
\hline 23 & 1 & 4 & 65 & 0 & 0 & 107 & 61,50 & 21 & 149 & 82,50 & 0,24 \\
\hline 24 & 20,00 & 0,29 & 66 & 41,00 & 0,24 & 108 & 62,00 & 0,20 & 150 & 83,00 & 0,25 \\
\hline 25 & 20,50 & 0,23 & 67 & & 0,24 & 109 & 62,50 & 0,21 & 151 & 83,50 & 0,33 \\
\hline 26 & 21,00 & 0,19 & 68 & 42,00 & 0,25 & 110 & 63,00 & 0,23 & 152 & 84,00 & 0,39 \\
\hline 27 & 21,50 & 4 & 69 & 42,50 & 0,24 & 111 & 63,50 & 0,35 & 153 & 84,50 & 0,27 \\
\hline 28 & 22,00 & 5 & 70 & 00 & 0,24 & 112 & 64,00 & 0,37 & 154 & 85,00 & 0,25 \\
\hline 29 & 22,50 & 0,29 & 71 & 50 & 0,31 & 113 & 64,50 & 0,23 & 155 & 85,50 & 0,27 \\
\hline 30 & 23,00 & 0,27 & 72 & 44,00 & 0,27 & 114 & 65,00 & 0,24 & 156 & 86,00 & 0,24 \\
\hline 31 & 23,50 & & 73 & 44,50 & 0,23 & 115 & 65,50 & 0,19 & 157 & 86,50 & 0,24 \\
\hline 32 & 24,00 & & 74 & & 0,21 & 116 & 66,00 & 0,19 & 158 & 87,00 & 0,24 \\
\hline 33 & 24,50 & 0,19 & 75 & 0 & 0,23 & 117 & 66,50 & 0,19 & 159 & 87,50 & 0,29 \\
\hline 34 & 25,00 & 0,19 & 76 & 46,00 & 0,20 & 118 & 67,00 & 0,19 & 160 & 88,00 & 0,51 \\
\hline 35 & 25,50 & 0,19 & 77 & 46,50 & 0,21 & 119 & 67,50 & 0,23 & 161 & 88,50 & 0,25 \\
\hline 36 & 26,00 & & 78 & & 0,24 & 120 & 68,00 & 0,27 & 162 & 89,00 & 0,20 \\
\hline 37 & 26,50 & 0,20 & 79 & 47,50 & 0,37 & 121 & 68,50 & 0,23 & 163 & 89,50 & 0,13 \\
\hline 38 & 27,00 & 0,19 & 80 & 48,00 & 0,37 & 122 & 69,00 & 0,23 & 164 & 90,00 & 0,11 \\
\hline 39 & 27,50 & 0,19 & 81 & 48,50 & 0,24 & 123 & 69,50 & 0,20 & 165 & 90,50 & 0,07 \\
\hline 40 & 28,00 & 0,20 & 82 & & 0,23 & 124 & 70,00 & 0,19 & & & \\
\hline 41 & 28,50 & 0,37 & 83 & 49,50 & 0,21 & 125 & 70,50 & 0,19 & & & \\
\hline 42 & 29,00 & 0,35 & 84 & 50,00 & 0,20 & 126 & 71,00 & 0,20 & & & \\
\hline
\end{tabular}

OBS: Os valores em negrito correspondem aos coletores localizados próximos aos microaspersores. 


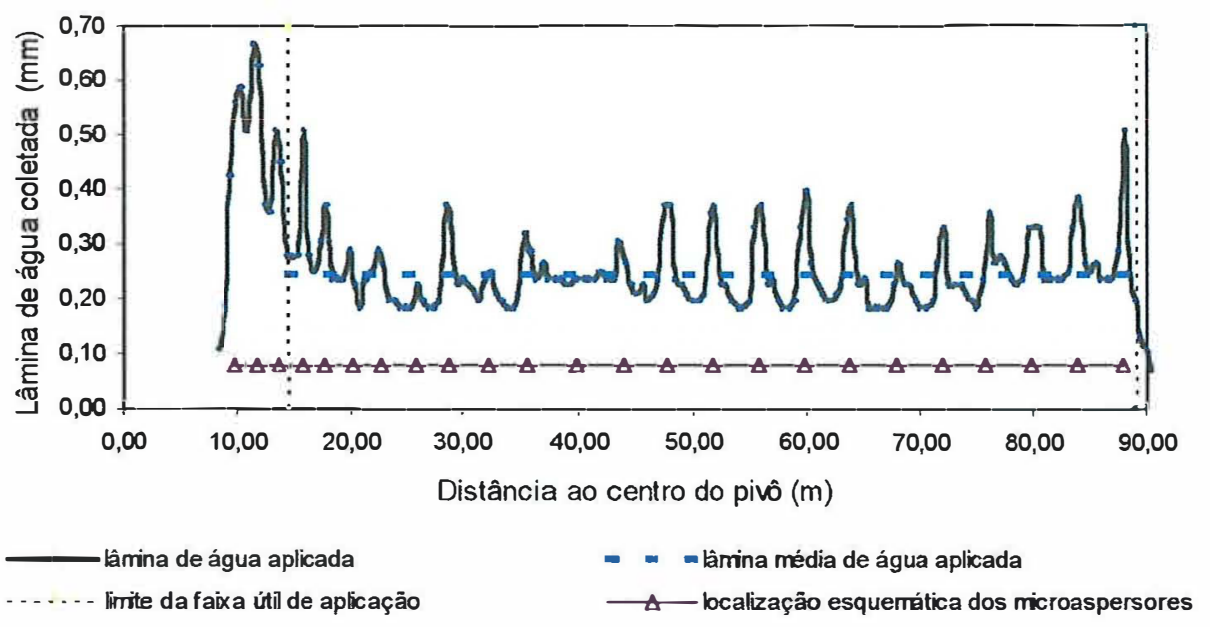

Figura 27 - Perfil das lâminas de água aplicadas pelos microaspersores; lâmina média de água aplicada; limites da faixa útil de aplicação e localização esquemática dos microaspersores.

empregados nos sistemas tratorizados e aéreos para aplicação de produtos químicos, o volume de 2430 litros por hectare é elevado, porém é muito inferior aos volumes aplicados freqüentemente em quimigação com sistemas de irrigação pivô central. As vantagens e desvantagens em aplicar maiores volumes de calda com diferentes produtos químicos devem ser melhor pesquisadas.

\subsection{Resultados do ensaio de uniformidade de aplicação de produtos químicos}

No ensaio de injeção de produtos químicos, uma solução concentrada de cloreto de potássio foi injetada no sistema através da bomba dosadora, de acordo com os procedimentos descritos no item 3.4.7. Antes do início do ensaio, a bomba dosadora foi regulada, através do disco graduado (Figura 9), para injetar uma vazão correspondente a $16 \%$ de sua vazão máxima, ou seja, $16 \%$ de $54 \mathrm{~L} / \mathrm{h}$, igual a $8,64 \mathrm{~L} / \mathrm{h}$. Medindo-se essa vazão injetada em 
condições de campo, obteve-se um valor de $8,73 \mathrm{~L} / \mathrm{h}$, que é muito próximo ao valor estimado, indicando uma grande precisão da bomba dosadora. Em cada microaspersor, que operava isoladamente, foi coletada uma amostra da solução aplicada. Nos locais do conjunto de emissão de calda onde operavam dois microaspersores conjuntamente (Figura 17), foram coletadas amostras de apenas um microaspersor, que já era suficiente para representar a concentração de potássio naqueles locais.

As concentrações de potássio (ppm) obtidas nas amostras coletadas nos microaspersores estão apresentadas na Tabela 12. A concentração de potássio na amostra de água coletada antes do início da injeção ("solução em branco") foi de 5 ppm e a amostra da solução concentrada injetada apresentou uma concentração de 39450ppm. Empregando-se essas concentrações, juntamente com a vazão de injeção medida de $8,73 \mathrm{~L} / \mathrm{h}$ e vazão total aplicada pelo sistema medida de 3456,26L/h, com a equação (10) calculou-se a concentração prevista da solução aplicada pelos microaspersores em 105ppm de potássio. A Figura 28 apresenta a variação da concentração de potássio aplicado pelos microaspersores ao longo do sistema. Observa-se esses valores apresentaram a mesma ordem de grandeza em relação a concentração estimada pela equação (10), com valores ligeiramente maiores que esse, indicando que o sistema de injeção de produtos químicos do protótipo operou de maneira eficiente.

\subsection{Desempenho do conjunto de acoplamento e regulagem da altura de aplicação}

O conjunto de acoplamento e regulagem da altura de aplicação promoveu uma perfeita sustentação do conjunto de emissão de calda. 
Tabela 12 - Valores das concentrações de potássio (ppm) aplicadas pelos microaspersores.

\begin{tabular}{|c|c|c|c|}
\hline $\begin{array}{c}\text { Distância do } \\
\text { microaspersor ao ponto } \\
\text { do pivô (m) }\end{array}$ & $\begin{array}{c}\text { Concentração de } \\
\text { potássio (ppm) }\end{array}$ & $\begin{array}{c}\text { Distância do } \\
\text { microaspersor ao ponto } \\
\text { do pivô (m) }\end{array}$ & $\begin{array}{c}\text { Concentração de } \\
\text { potássio (ppm) }\end{array}$ \\
\hline 9,8 & 104 & 43,8 & 115 \\
\hline 11,8 & 110 & 47,8 & 113 \\
\hline 13,8 & 115 & 51,8 & 106 \\
\hline 15,8 & 104 & 55,8 & 115 \\
\hline 17,8 & 105 & 59,8 & 104 \\
\hline 20,3 & 114 & 63,8 & 104 \\
\hline 22,8 & 112 & 67,8 & 120 \\
\hline 25,8 & 105 & 71,8 & 110 \\
\hline 28,8 & 107 & 75,8 & 117 \\
\hline 32,3 & 105 & 79,8 & 116 \\
\hline 35,8 & 116 & 83,8 & 109 \\
\hline 39,8 & 110 & 87,8 & \\
\hline
\end{tabular}

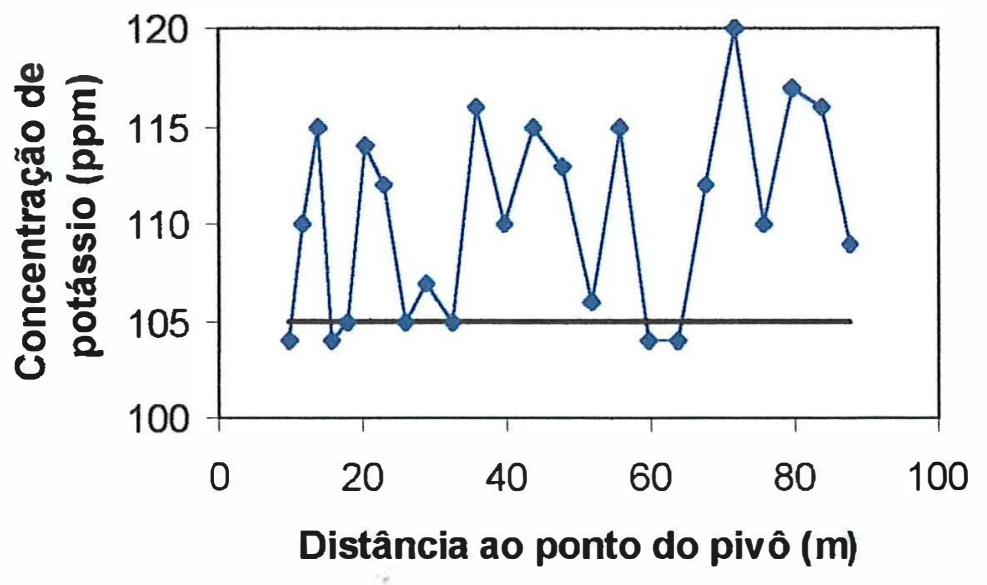

$\prec$ concentração de potássio medida (ppm)

— concentração de potássio estimada (ppm)

Figura 28 - Variação das concentrações de potássio (ppm) aplicadas pelos microaspersores. 


\section{CONCLUSÕES}

Com base nos métodos e equipamentos utilizados no desenvolvimento do protótipo e nos resultados obtidos nos ensaios de campo, pode-se concluir que:

a) os componentes desenvolvidos para a composição do protótipo aplicador de produtos químicos apresentaram bom desempenho em condiçð̃es de campo;

b) a metodologia para o dimensionamento hidráulico do sistema foi eficiente, com as vazões e pressð̃es medidas com valores próximos aos calculados;

c) o protótipo apresentou boa uniformidade de distribuição de água, com variaçð̃es próximas aos microaspersores, devido a respingos causados pelos impactos dos jatos de água no corpo dos mesmos;

d) a injeção da solução concentrada de cloreto de potássio com a bomba dosadora proporcionou concentração uniforme de potássio na solução emitida pelos microaspersores. 


\section{REFERÊNCIAS BIBLIOGRÁFICAS}

BOTREL, T.A. Hidráulica de microaspersores e de linhas laterais para irrigação localizada. Piracicaba 1984. 78p. Dissertação (Mestrado) - Escola de Superior de Agricultura "Luiz de Queiroz", Universidade de São Paulo.

CAMPOS, H. Estatística experimental não-paramétrica. 4.ed. Piracicaba: ESALQ/USP, 1983.349p.

COELHO, R.D. Caracterização física do sistema de irrigação pivô central (LEPA) operando em condições de microrelevo condicionado. São Carlos, 1996. 178p. Tese (Doutorado) - Escola de Engenharia de São Carlos, Universidade de São Paulo.

DOURADO-NETO, D.; FANCELLI, A.L. Quimigação na cultura do feijão. In: Folegatti, M.V. (Ed.) Fertirrigação: citrus, flores, hortaliças. Guaíba: Agropecuária, 1999. Cap.5, p.393-432.

FRIZZONE, J.A. Irrigação por aspersão: uniformidade e eficiência. Piracicaba: ESALQ/USP, 1992. 53p. (Departamento de Engenharia Rural. Série Didática, 3)

LYLE, W.M.; BORDOVSKY; J P. Chemical application with the multifunction LEPA system. Transactions of the ASAE, v.29, n.6, p.1699-1706, 1986. 
MACINTYRE, A. J. Bombas e instalações de bombeamento. 2.ed. Rio de Janeiro: Guanabara, 1987. 782p.

MAIA, L.A.F. Desenvolvimento de um software para auxiliar no dimensionamento e manejo da irrigação localizada. Piracicaba, 1994. 158p. Dissertação (Mestrado) - Escola de Superior de Agricultura "Luiz de Queiroz", Universidade de São Paulo.

MARCHETTI, D. Irrigação por pivô central. Brasília: EMBRAPA, 1983. 23p. (Circular Técnica Número 1)

OMARY, M.; CAMP, C.R.; SADLER, E.J. Center pivot irrigation system modification to provide variable water application depths. Applied Engineering in Agriculture, v. 13, n.2, p.235-239, 1997.

SCHIMIDT. W. Quimigação: Características, vantagens e desvantagens. In: SEMINÁRIO DE QUIMIGAÇÃO, 1., Barreiras, 1997. Anais. São Paulo: DowElanco, 1997. p.46-54.

SUMNER, H. R.; GARVEY, P. M.; HEERMANN, D.F.; CHANDLER, L.D. Center pivot irritation attached sprayer. Applied Engineering in Agriculture, v. 13, n.3, p.323-327, 1997.

SUMNER, H.R.; DOWLER, C.C.; GARVEY, P.M. Application of agrichemicals by chemigation, pivot-attached sprayer systems, and conventional sprayers. Applied Engineering in Agriculture, v.16, n.2, p. 103-107, 2000.

TECH TIPS. Hanging plastic pipes growing in popularity. Irrigation Advances, v.8, n.1, p.9-12, 1999. 